Article

\title{
Archaean Gold Mineralization in an Extensional Setting: The Structural History of the Kukuluma and Matandani Deposits, Geita Greenstone Belt, Tanzania
}

\author{
Shimba D. Kwelwa ${ }^{1,2}$, Paulus H. G. M. Dirks ${ }^{1,3}{ }^{\mathbb{D}}$, Ioan V. Sanislav ${ }^{1,3, *}$, Thomas Blenkinsop ${ }^{4}$ \\ and Sergio L. Kolling ${ }^{2}$ \\ 1 Economic Geology Research Centre (EGRU), Townsville, QLD 4811, Australia; \\ skwelwa@anglogoldashanti.com (S.D.K.); paul.dirks@jcu.edu.au (P.H.G.M.D.) \\ 2 Geita Gold Mine, Geita, P.O. Box 532, Geita Region, Tanzania; \\ skolling@anglogoldashanti.com or slkolling@yahoo.com \\ 3 Department of Geosciences, James Cook University, Townsville, QLD 4811, Australia \\ 4 School of Earth \& Ocean Sciences, Cardiff University, Cardiff CF10 3AT, UK; blenkinsopt@cardiff.ac.uk \\ * Correspondence: ioan.sanislav@jcu.edu.au; Tel.: +61-07-4781-3293
}

Received: 22 March 2018; Accepted: 22 March 2018; Published: 21 April 2018

check for updates

\begin{abstract}
Three major gold deposits, Matandani, Kukuluma, and Area 3, host several million ouncez (Moz) of gold, along a $\sim 5 \mathrm{~km}$ long, WNW trend in the E part of the Geita Greenstone Belt, NW Tanzania. The deposits are hosted in Archaean volcanoclastic sediment and intrusive diorite. The geological evolution of the deposits involved three separate stages: (1) an early stage of syn-sedimentary extensional deformation $\left(\mathrm{D}_{1}\right)$ around $2715 \mathrm{Ma}$; (2) a second stage involving overprinting ductile folding $\left(\mathrm{D}_{2-4}\right)$ and shearing $\left(\mathrm{D}_{5-6}\right)$ events during N-S compression between 2700 and $2665 \mathrm{Ma}$, coeval with the emplacement of the Kukuluma Intrusive Complex; and (3) a final stage of extensional deformation $\left(\mathrm{D}_{7}\right)$ accommodated by minor, broadly east-trending normal faults, preceded by the intrusion of felsic porphyritic dykes at $\sim 2650 \mathrm{Ma}$. The geometry of the ore bodies at Kukuluma and Matandani is controlled by the distribution of magnetite-rich meta-ironstone, near the margins of monzonite-diorite bodies of the Kukuluma Intrusive Complex. The lithological contacts acted as redox boundaries, where high-grade mineralization was enhanced in damage zones with higher permeability, including syn- $\mathrm{D}_{3}$ hydrothermal breccia, $\mathrm{D}_{2}-\mathrm{D}_{3}$ fold hinges, and $\mathrm{D}_{6}$ shears. The actual mineralizing event was syn- $\mathrm{D}_{7}$, and occurred in an extensional setting that facilitated the infiltration of mineralizing fluids. Thus, whilst gold mineralization is late-tectonic, ore zone geometries are linked to older structures and lithological boundaries that formed before gold was introduced. The deformation-intrusive history of the Kukuluma and Matandani deposits is near identical to the geological history of the world-class Nyankanga and Geita Hill deposits in the central part of the Geita Greenstone Belt. This similarity suggests that the geological history of much of the greenstone belt is similar. All major gold deposits in the Geita Greenstone Belt lack close proximity to crustal-scale shear zones; they are associated with intrusive complexes and volcanics that formed in an oceanic plateau rather than subduction setting, and formed late-tectonically during an extensional phase. They are not characteristic of typical orogenic gold deposits.
\end{abstract}

Keywords: Archaean gold; Tanzania; structural controls; deformation; Kukuluma; Geita; orogenic gold

\section{Introduction}

Archean deposits are a major source for gold across most cratonic regions in the world [1-4]. Except for gold deposits linked to supra-crustal basins, such as the giant deposits in the Witwatersrand 
Basin, the bulk of Archean gold is hosted within or adjacent to greenstone belts; these are commonly classified as orogenic [5-9] or Archaean lode gold deposits, to use a less generic term.

Archean orogenic gold deposits show many common features, including a common association with major fault systems that cut volcano-sedimentary sequences in greenstone belts (e.g., $[4,10])$. These faults channel mineralising fluids from deeper crustal levels to traps in an episodic manner through seismic pumping [11,12]. The fluids that transport the gold are typically aqueous-carbonic fluids, with 5-20 mol \% $\mathrm{CO}_{2}$, derived from metamorphic devolatilization reactions [8], and are associated with a quartz-carbonate alteration and a low-sulphidation ore assemblage dominated by pyrite-arsenopyrite, with deposition typically (but not exclusively) occurring in greenschist facies domains [6,13].

Whilst many studies of world-class gold deposits in well-endowed areas, such as the Yilgarn and Superior Cratons, suggest that mineralization involved multiple stages of gold enrichment [13-17], evidence for this can be equivocal, because of the complexities associated with structural overprints and reactivations of peak-metamorphic shear zones during later events [18]. Some authors [9] argue strongly that the notion of multiple mineralizing events is wrong, and that all orogenic gold deposits, including the Archean deposits, formed during a single late-tectonic stage and in a subduction-related tectonic setting in accretionary to collisional orogenic belts, where fluid flow is driven by a change in far-field stress shortly before cratonization [9]. By classifying the deposits in this way, Archaean gold deposits are placed in a plate-tectonic setting that is similar to today-a contention that remains strongly contested [18-22].

Because gold mineralization occurs late in most granite-greenstone terrains $[2,6,9,18]$, irrespective of what underlying tectonic model is applied, gold trapping structures can be highly diverse in geometry, and will be controlled by the interplay of multiple overprinting deformational and intrusive events [9]. To understand the detailed structural architecture of a greenstone sequence in relation to the timing of mineralization is therefore important when working out gold distribution patterns. The aim of this study is to do this for a set of major gold deposits in a relatively poorly known greenstone sequence in the Lake Victoria goldfield in Tanzania (Figures 1 and 2)

The Geita Greenstone Belt (GGB) in the northern part of the Tanzania Craton (Figure 1) hosts world-class gold deposits spread along a $35 \mathrm{~km}$ long corridor in the central part of the greenstone belt (Figure 2). These deposits, include (from west to east) the Star and Comet, Nyangkanga, Lone Cone, Geita Hill, Matandani, and Kukuluma deposits (Figure 2), and are commonly referred to collectively as the Geita mine [7]. All these deposits are largely hosted in silicified, magnetite-rich metasedimentary units (referred to in the mine as meta-ironstones) near the intrusive contacts of monzonitic to dioritic bodies that intruded the greenstone belt [23-26]. 


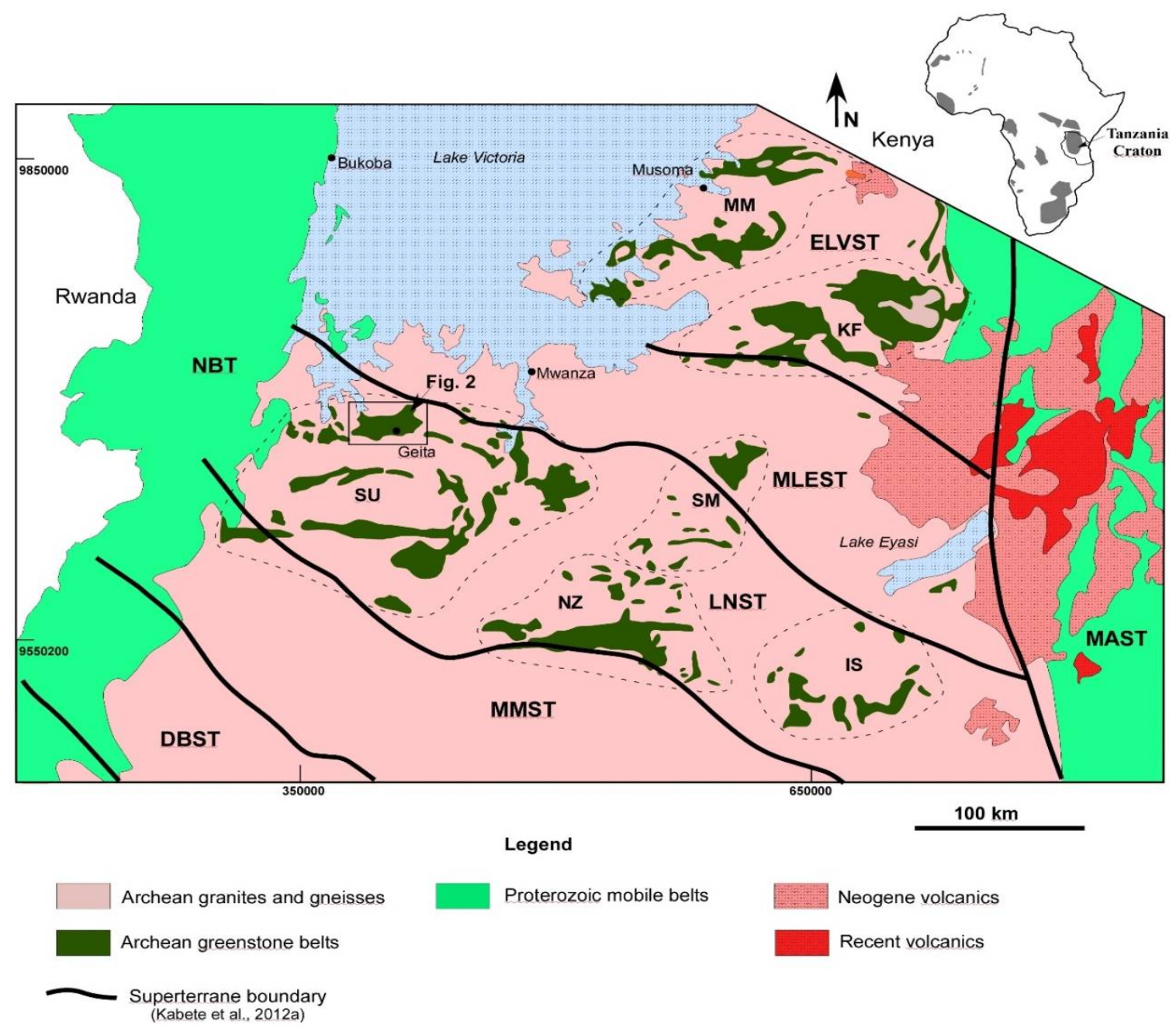

Figure 1. Geological map of the northern half of the Tanzania Craton, showing the main geological and tectonic units: IS-Iramba-Sekenke Greenstone Belt; KF-Kilimafedha Greenstone Belt; MM-Musoma-Mara Greenstone Belt; NZ—Nzega Greenstone Belt; SM-Shinyanga-Malita Greenstone Belt; SU—Sukumaland Greenstone Belt. Super-terrane boundaries are as proposed by [27]: DBST_Dodoma Basement; ELVST_East Lake Victoria; LNST_Lake Nyanza; MAST_Mbulu-Masai; MLEST-Mwanza Lake Eyasi; MMST-Moyowosi-Manyoni; NBT-Nyakahura-Burigi. The inset map of Africa shows the location of Archaean blocks. The figure has been adapted from [25]. The red square shows the study area as shown in Figure 2.

To date no detailed work has been published on the major deposits that occur in the eastern part of the GGB (Figures 2 and 3). These include the Matandani, Kukuluma, and Area 3 deposits that collectively host several Moz of gold. In this paper, a deformation model for the area around the Matandani and Kukuluma pits will be presented, based on detailed mapping and core logs from the pits and surrounding areas. The deformation model will be linked to the relative timing of intrusive units and gold mineralization, and forms the basis for geochemical and geochronological studies in the area $[26,28]$. 


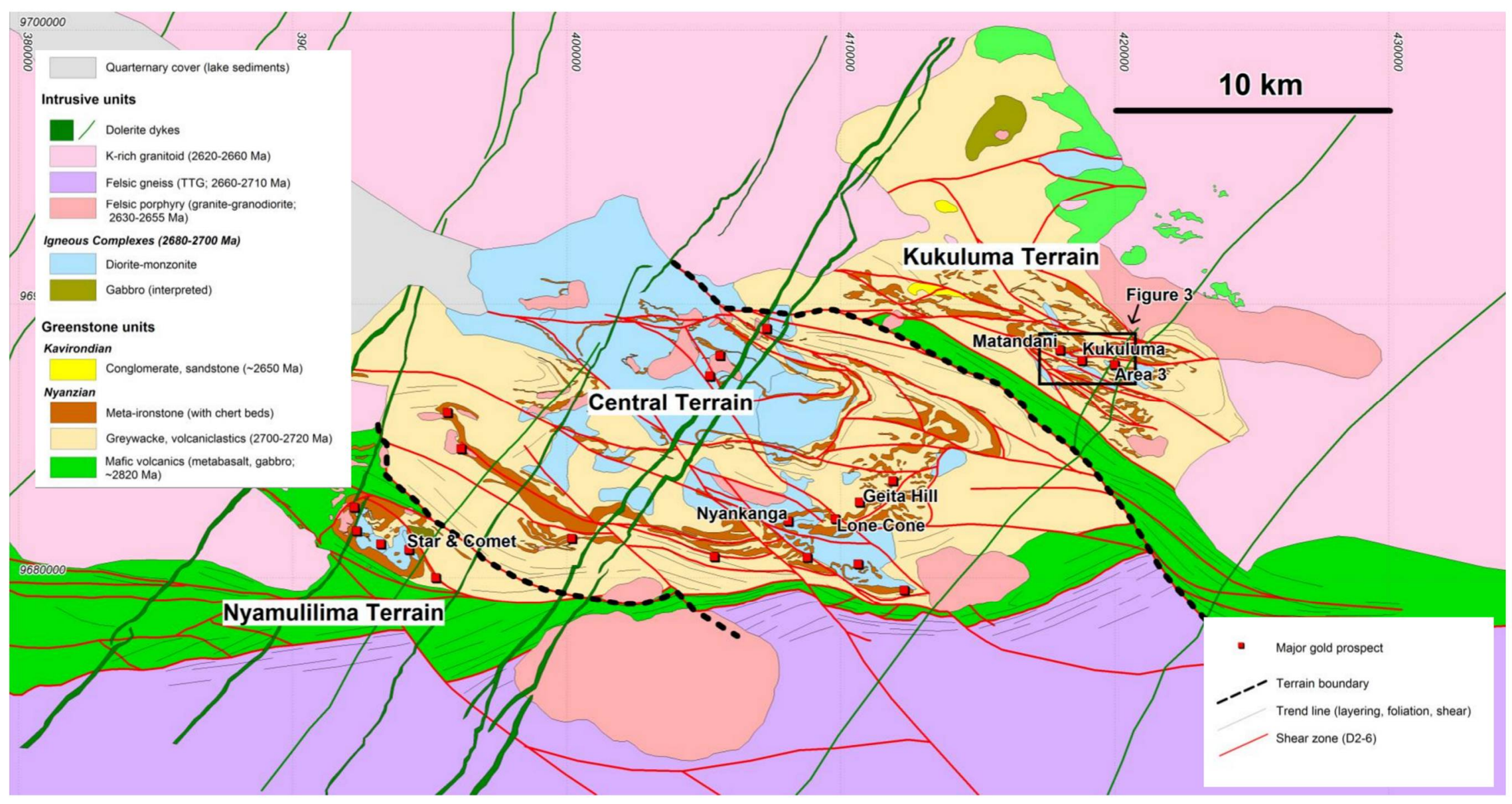

Figure 2. Geological map of the Geita Greenstone Belt, showing the location of the major gold deposits and the main geological terrains, lithological units, and structures (listed ages from $[25,28,29]$ ). The insert shows the study area in Figure 3. The grid is in UTM WGS84, zone 36S. 


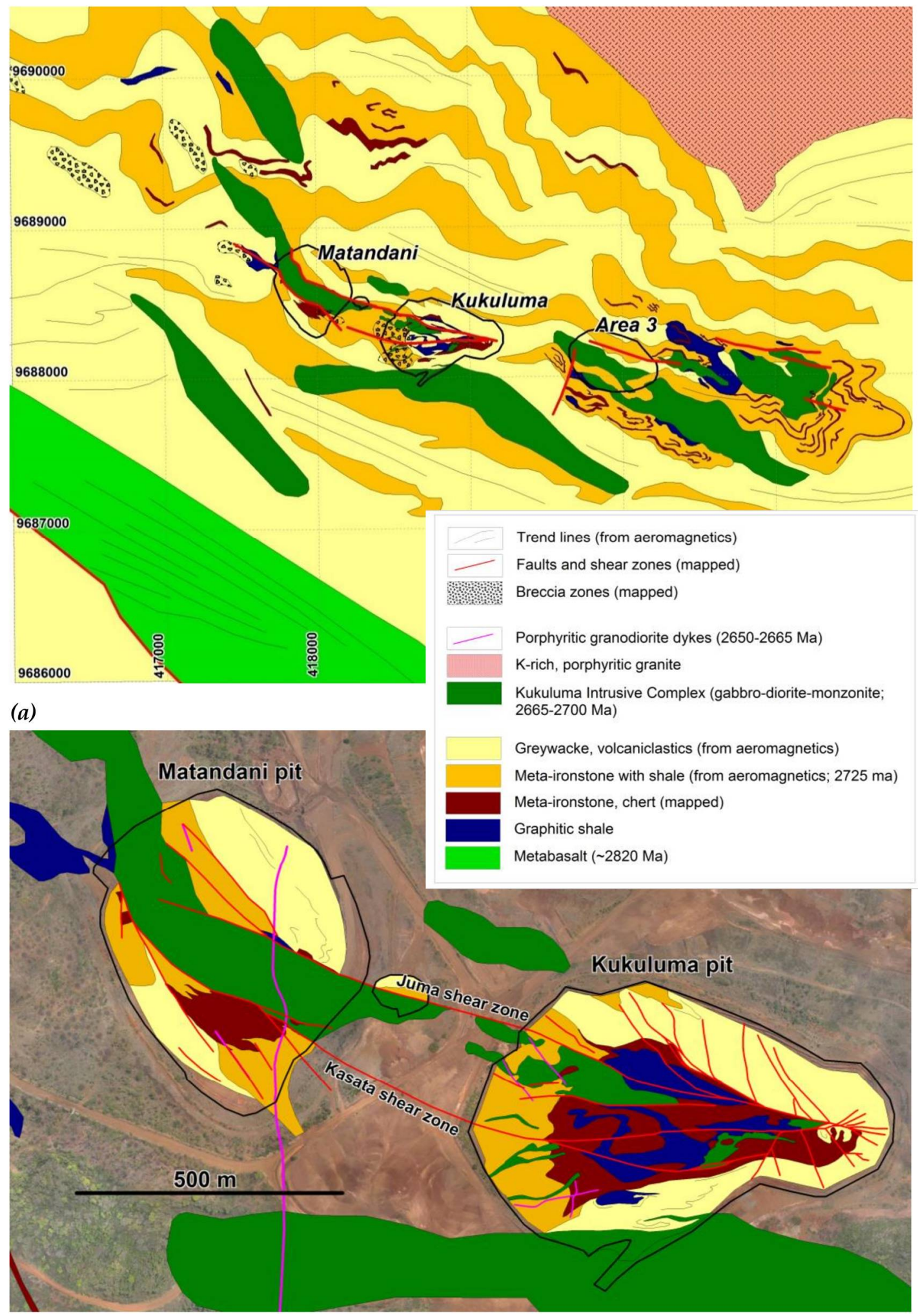

(b)

Figure 3. (a) Geological map of the central Kukuluma Terrain, showing the position of the main gold deposits in the area. The distribution of the meta-ironstones in the area is derived from geophysics. Map projection is UTM WGS84 zone 36S; (b) Close-up view of the Matandani and Kukuluma pits. The age estimates in the legend are from [28-30]. 


\section{Regional Geological Framework}

The Tanzania craton consists of a core of $>3.0$ giga annum $(\mathrm{Ga})$ high-grade mafic and felsic granulite (the Dodoman Supergroup), overlain by a volcano-sedimentary package dominated by mafic volcanics (the 2820-2700 Ma Nyanzian Supergroup) and younger (<2650 Ma), mostly coarse clastic sediment of the Kavirondian Supergroup [31-37]. Rocks belonging to the Dodoman Supergroup are restricted to the southern part of the craton, with the northern craton comprised of younger $(<2.82 \mathrm{Ga})$, juvenile crust $[36,38,39]$. The latter has been alternatively interpreted as accretionary volcanic arc systems [40] or vertically accreting and chemically evolving oceanic plateaus [39] that docked with the older cratonic core during the Neoarchaean.

The Nyanzian and Kavirondian sequences in the northern part of the Tanzania Craton have been grouped into six greenstone belts (Figure 1) clustered around the margins of Lake Victoria [34]. Each of these greenstone belts comprises a series of disconnected greenstone domains that were grouped based on perceived stratigraphic correlations and geographic proximity [41], in spite of the presence of large shear zones that separate parts of each greenstone belt [27]. Of the six greenstone belts, the Sukumaland Greenstone Belt is the largest, containing fragments that are large enough, and tectonically and stratigraphically distinct enough to be categorized as greenstone belts in their own right. This includes a greenstone domain along the northern margin of the Sukumaland Greenstone Belt, which we have termed the Geita Greenstone Belt (Figure 2), following terminology introduced by $[25,37]$.

\subsection{The Geita Greenstone Belt (GGB)}

The Geita Greenstone Belt (GGB, Figure 2) forms an $80 \mathrm{~km} \times 25 \mathrm{~km}$ large, generally east-west trending portion of mafic-felsic volcanic, volcanoclastic, and sedimentary rocks, bounded to the south by a large, east-west trending shear zone that separates the belt from gneiss and mylonitic granitoid [29]. To the north, east, and west the greenstone units were intruded by late syn- to post-tectonic granitoid plutons dated at 2660-2620 Ma [30]. The southern part of the GGB contains meta-basalt, with minor gabbro and a MORB-like affinity yielding ages of $\sim 2823 \mathrm{Ma}[36,37]$, which were deposited through vertical melt segregation in an oceanic plateau environment $[37,39]$. The remainder of the greenstone belt is dominated by meta-ironstone units intercalated with and overlain by turbiditic meta-sedimentary units and volcanoclastic beds older than $2699 \pm 9$ Ma [25,35]. These units were intruded by syn-tectonic igneous complexes of dioritic to tonalitic composition [24-26]. The diorite intrusive complex around Nyankanga and Geita Hill were dated at $2686 \pm 13 \mathrm{Ma}$ and $2699 \pm 9 \mathrm{Ma}$ (U-Pb zircon, [35]), and the intrusive complex around Kukuluma at between $2717 \pm 12 \mathrm{Ma}$ and $2667 \pm 17 \mathrm{Ma}$ (Figures 2 and 3, [26,28]).

Meta-ironstone units are exposed in three distinct northwest-southeast trending terrains, separated by areas with little or no outcrop underlain by meta-sediments. The boundaries of these terrains are characterized by major lineaments visible on aero-magnetic datasets and interpreted as large shear zones (Figure 2). These terrains are the Nyamulilima terrain to the west, the Central terrain in the middle, and Kukuluma terrain to the east (Figure 2). The Kukuluma terrain contains the Matandani and Kukuluma deposits, which were mined until 2007 (Figures 2 and 3). The nearby Area 3 deposit is undeveloped.

Initial models for the deformation history of the GGB invoked early upright folding, overprinted by a second folding event characterized by steeply plunging axes and cut by later regional and subsidiary shear zones, which represent the main pathways for hydrothermal fluids [23,33,41]. Mine models in the early 2000s assumed that mineralized shear zones in the GGB were part of complex thrust stacks associated with horizontal shortening and stacking of the greenstone sequence, with gold mineralization concentrating in dilatant zones along thrusts and near fold hinges [42,43]. Subsequent mining has demonstrated that complex thrust stacks with stratigraphic duplication do not exist, but instead that gold is related to a complex interplay of folding and intrusive events cut by late, mainly eastern-trending fracture zones as seen in the Nyankanga and Geita Hill deposits (Figure 2, [24,25]). 
Detailed structural work in these deposits [24,25] has shown that the mineralization is centered on northwest dipping reverse faults (referred to in Geita Hill as $\mathrm{D}_{6}$ ) that overprint a complexly folded (referred to in Geita Hill as $\mathrm{D}_{1-5}$ ) stack of meta-ironstone and chert, and were reactivated as later normal faults at the time of mineralization (called $\mathrm{D}_{8}$ at Geita Hill). Gold-deposition preferentially occurred along diorite-meta-ironstone contacts exploited by the fracture systems [24,25] after emplacement of a lamprophyre dyke at $2644 \pm 3 \mathrm{Ma}$ [35], i.e., 20-30 Ma later than the formation of reverse faults [24].

\subsection{Stratigraphy of the Kukuluma Terrain}

A generalized stratigraphic column for the Kukuluma terrain is presented in Figure 4. This column has been reconstructed from mapping and drilling around the Kukuluma and Matandani pits, as presented in this study, combined with age constraints from intercalated volcaniclastics and cross-cutting porphyry dykes [28]. The Kukuluma terrain is bounded to the west by a major northwest-trending shear zone, which juxtaposes lower greenschist facies meta-sediments of the Central terrain, and lower amphibolite facies mafic to ultramafic meta-basalts at the stratigraphic base of the Kukuluma terrain (Figure 2; [37]).

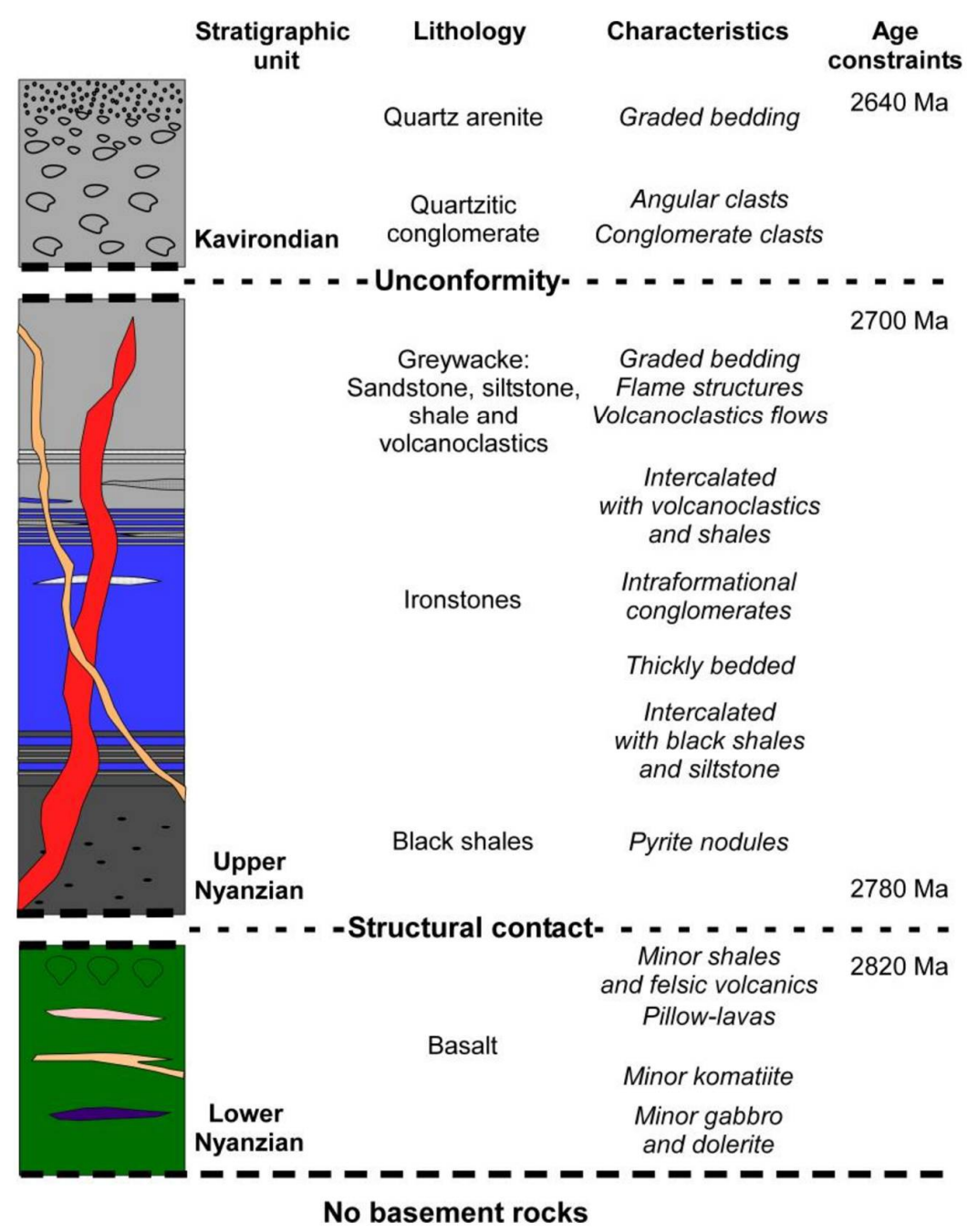

Figure 4. Summary stratigraphy for the Kukuluma terrain. Age constraints are from [28,37].

The sedimentary sequence in the central parts of the Kukuluma terrain is composed of a volcano-sedimentary pile with a black, graphitic shale unit of undefined thickness (pit outcrops indicate a minimum thickness of $\sim 30 \mathrm{~m}$ ) at its base. This unit is well-exposed at the bottom of 
the Kukuluma pit, and probably overlies metabasalt [28]. The black shale unit transitions into a well-layered meta-ironstone unit that is variable in thickness due to deformational effects (described below). The meta-ironstone unit is widely distributed (Figure 3), and consists of regularly layered packages of magnetite-rich sandstone and siltstone interlayered with shale beds and silicified, quartzite beds. The meta-ironstone unit transitions into meta-greywacke, comprised of laminated shale- to sandstone beds (Figure 4) interlayered with fine-grained meta-tuff and volcaniclastics. The greywackes have characteristics similar to deposits laid down on the proximal parts of a marine fan-delta system, with input of immature sediment [44]. Rocks of the Upper Nyanzian are intruded by diorites, monzonites, and granodiorites of the Kukuluma Intrusive Complex (Figure 4). In the northern part of the Kukuluma terrain, the meta-ironstone and meta-greywacke units are unconformably overlain by cross-bedded sandstone and clast, supported conglomerate ascribed to the Kavirondian Supergroup.

\section{The History of Deformation in the Kukuluma Terrain}

The deformation events in the Kukuluma-Matandani area comprise three groups of structures: (1) structures that formed during an extensional deformation episode $\left(D_{1}\right)$ at the time of sedimentation and early volcanism, which are best preserved in drill core; $(2)$ penetrative structures $\left(D_{2}-D_{6}\right)$ involving overprinting folding, shearing, and brecciation events, which occurred when the rocks mostly behaved in a ductile manner during the main compressional stage of deformation; and (3) localized late tectonic structures that formed during extensional deformation, when strain was partitioned into discrete normal faults and joints $\left(D_{7}\right)$. Deformation events were accompanied by the emplacement of syn-tectonic intrusions of the Kukuluma Intrusive Complex (KIC, [26]). A mineralized, late-tectonic felsic porphyry dyke cross-cuts all units, and provides an upper age constraint for gold mineralization in the area [28].

The deformation events have been summarized in Table 1 and are described in detail below. In reading the deformation history, it is important to realize that the $\mathrm{D}_{1}-\mathrm{D}_{6}$ deformation geometries, in combination with intrusive boundaries, provide the deformational architecture that trap the auriferous fluids, which percolated late in the deformation history of the area [9].

Table 1. Summary of deformation and intrusive events that affect the Kukuluma terrain. Listed age estimates are based on $[25,28,29]$. Mineralization occurs during $\mathrm{D}_{7}$ events, and gold-bearing fluids are trapped in structures of $\mathrm{D}_{1}$ to $\mathrm{D}_{6}$ origin. Apy = arsenopyrite; $\mathrm{Po}=$ pyrrhotite; $\mathrm{Py}=$ pyrite.

\begin{tabular}{|c|c|c|c|}
\hline $\begin{array}{l}\text { Deform. } \\
\text { Event }\end{array}$ & Intrusive Event [Age] & Description of Structures & $\begin{array}{l}\text { Mineralization } \\
\text { [Trapping Structures] }\end{array}$ \\
\hline$D_{1}$ & $\begin{array}{l}\text { Volcanism } \\
(2715 \mathrm{Ma})\end{array}$ & $\begin{array}{l}\text { Layer-parallel shears } \\
\text { Growth faulting }\end{array}$ & $\begin{array}{l}\text { Mineralisation trapped by } \\
\text { Fe-rich lithologies }\end{array}$ \\
\hline$D_{2}$ & $\begin{array}{l}\text { Start of emplacement of } \\
\text { KIC: } \\
\text { Gabbro-diorite- } \\
\text { monzonite suite } \\
(2700-2680 \mathrm{Ma})\end{array}$ & $\begin{array}{l}\text { Non-cylindrical folding } \\
\text { (1-500 m scale) } \\
\text { Formation of penetrative } \\
\mathrm{S}_{2} \text { fabric } \\
\text { Sills, dykes and plugs }\end{array}$ & $\begin{array}{l}\text { Mineralization in } \mathrm{F}_{2}-\mathrm{F}_{3} \text { fold } \\
\text { hinge zones } \\
\text { Mineralization along } \\
\text { diorite-ironstone contacts }\end{array}$ \\
\hline$D_{3}$ & $\begin{array}{l}\text { Further emplacement } \\
\text { of KIC: } \\
\text { Gabbro-diorite- } \\
\text { monzonite suite } \\
(2700-2680 \mathrm{Ma})\end{array}$ & $\begin{array}{l}\text { Folding on } 1-500 \mathrm{~m} \text { scale } \\
\text { Plunge varies across } \mathrm{F}_{2} \text { fold limbs } \\
\text { Associated with } \mathrm{S}_{3} \text { axial planar } \\
\text { cleavage that dips steeply SW } \\
\text { High-strain domains bound } \\
\text { folded domains } \\
\text { Emplacement of KIC along } \mathrm{D}_{3} \\
\text { axial planes with } \mathrm{S}_{3} \text { fabric in KIC } \\
\text { Extensive brecciation of } \mathrm{D}_{2}-\mathrm{D}_{3} \\
\text { folded ironstone near margins } \\
\text { of KIC }\end{array}$ & $\begin{array}{l}\text { Mineralization trapped along } \mathrm{F}_{3} \\
\text { fold axial planes characterized } \\
\text { by microfracturing } \\
\text { Mineralization in breccia zones }\end{array}$ \\
\hline
\end{tabular}


Table 1. Cont.

\begin{tabular}{|c|c|c|c|}
\hline $\begin{array}{l}\text { Deform. } \\
\text { Event }\end{array}$ & Intrusive Event [Age] & Description of Structures & $\begin{array}{l}\text { Mineralization } \\
\text { [Trapping Structures] }\end{array}$ \\
\hline$D_{4}$ & & $\begin{array}{l}\text { Open, cylindrical upright folding } \\
\text { Symmetric folds plunge steeply } \\
\text { WNW } \\
\text { Limited } \mathrm{S}_{4} \text { fabric development }\end{array}$ & \\
\hline \multicolumn{2}{|c|}{$\begin{array}{l}\mathrm{D}_{5} \\
\mathrm{~N}-\mathrm{S} \text { compression }\end{array}$} & $\begin{array}{l}\text { Open cylindrical recumbent folds } \\
\text { Low angle reverse faults with } \\
\text { small offsets }(<10 \mathrm{~m})\end{array}$ & \\
\hline & $\begin{array}{l}\text { Further emplacement } \\
\text { of KIC: } \\
\text { Granodiorite suite } \\
(2680-2665 \mathrm{Ma})\end{array}$ & $\begin{array}{l}\text { Felsic porphyry dykes truncate } \\
D_{1-4} \text { folds }\end{array}$ & \\
\hline \multirow[t]{2}{*}{$\begin{array}{l}D_{6} \\
\text { N-S compressio }\end{array}$} & & $\begin{array}{l}\mathrm{NW} \text { to WNW trending, steeply } \\
\text { dipping, brittle ductile shear } \\
\text { zones. } \\
\text { Dextral-reverse } \\
\text { Fracture networks overprint } \\
\mathrm{F}_{2}-\mathrm{F}_{3} \text { folds and breccia zones } \\
\text { Associated with tectonic breccia }\end{array}$ & $\begin{array}{l}\mathrm{D}_{6} \text { shear zones and associated } \\
\text { damage zones facilitate fluid } \\
\text { infiltration and fluid-rock } \\
\text { interaction }\end{array}$ \\
\hline & $\begin{array}{l}\text { Emplacement of felsic } \\
\text { dykes ( } 2650 \mathrm{Ma})\end{array}$ & $\mathrm{N}$ trending felsic porphyry dyke & Mineralization overprints dykes \\
\hline \multirow[t]{2}{*}{$\begin{array}{l}D_{7} \\
\text { N-S extension }\end{array}$} & & $\begin{array}{l}\text { Normal faulting } \\
\text { Reactivation of } \mathrm{D}_{6} \text { shears as } \\
\text { sinistral normal faults }\end{array}$ & $\begin{array}{l}\mathrm{D}_{7} \text { shear zones are mineralized, } \\
\text { and acted as the main fluid } \\
\text { channel ways apy-po-py ore } \\
\text { assemblage }\end{array}$ \\
\hline & $\begin{array}{l}\text { Granitoids plutons } \\
\text { (2620-2640 Ma) }\end{array}$ & & \\
\hline
\end{tabular}

\section{1. $D_{1}$ Normal Faulting and Bedding Parallel Shearing Events}

$D_{1}$ comprises a complex family of structures that formed prior to the development of $D_{2}$ folds. These structures formed in part during sedimentation of the meta-ironstone and meta-greywacke sequences, and partly after these units were buried (presumably as extension-sedimentation continued higher up in the stratigraphy). Centimeter-scale growth faulting visible in the drill core in meta-sediment indicates active extension during sedimentation. In places, the growth faults are listric, and associated with layer-parallel zones of brecciation and folding characterized by $\mathrm{cm}$ - to $\mathrm{dm}$-scale disharmonic folding, interpreted as layer-parallel deformation zones similar to low-angle detachments.

Meta-ironstone units preserve an early-layer-parallel foliation $\left(\mathrm{S}_{1}\right)$ that locally intensifies. A good example of this occurs along the access ramp into Kukuluma pit between GR (grid reference) 418900-9688150 and 418950-9688180 (all grid references are in WGS84, zone 36S), where a well-layered greywacke unit is intruded by dark grey, planar quartz veins with a chert-like appearance (Figure 5a). Over a horizontal distance of about $15 \mathrm{~m}$, the density of these intrusive veins increases as the rock changes from bedded meta-greywacke into a massive glassy chert, and coarser grained sandstone beds are boudinaged. $S_{1}$ is well-developed in this zone, together with rare intrafolial folds, dextral shear bands, and an $\mathrm{L}_{1}$ mineral lineation, and the zone is interpreted as a $\mathrm{D}_{1}$ shear zone. Although the shear sense across this zone is unclear, it cuts out part of the stratigraphy, which together with the associated boudinaging and extension of the host rock layering suggests an extensional origin. It may link to basin opening, and is interpreted to represent a deeper level manifestation of the syn-sedimentary growth faults seen in drill core. 


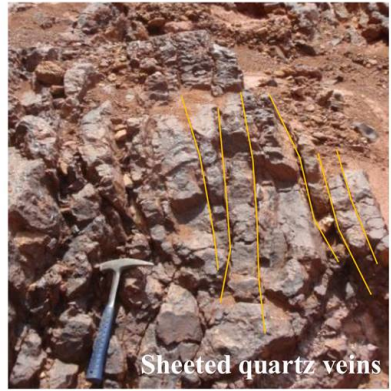

(a)

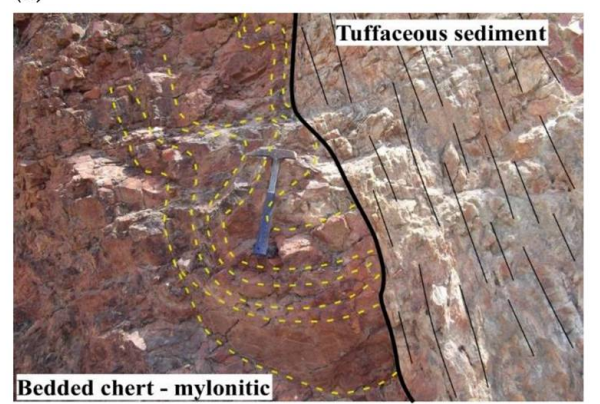

(c)

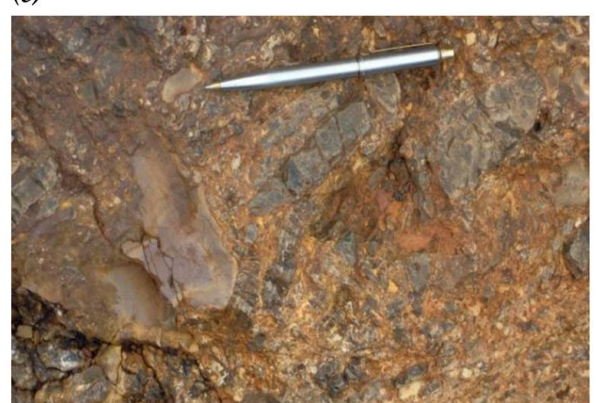

(e)

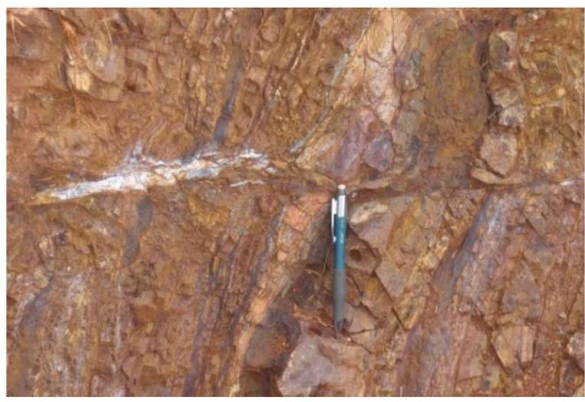

(g)

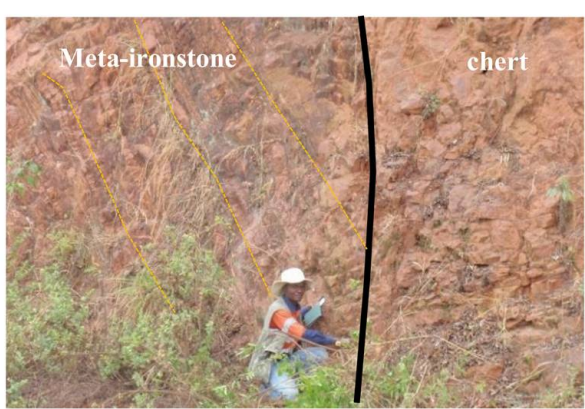

(b)

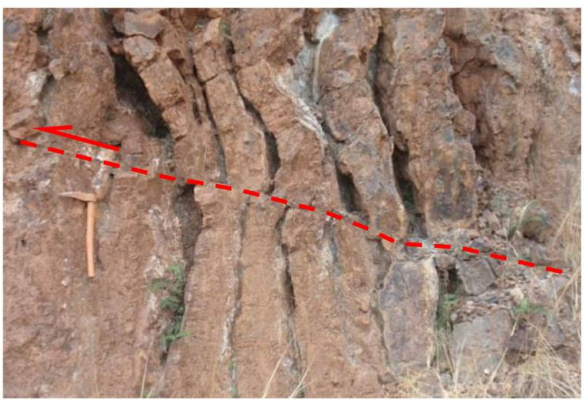

(d)

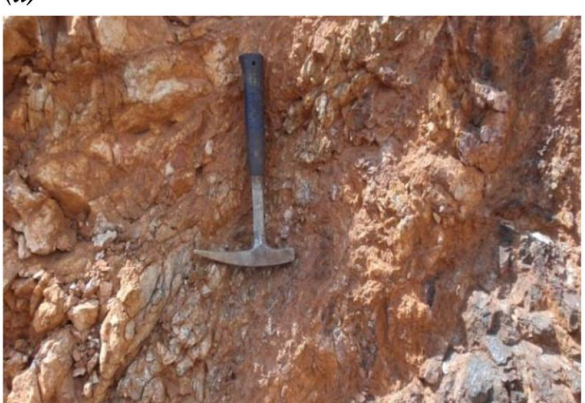

(f)

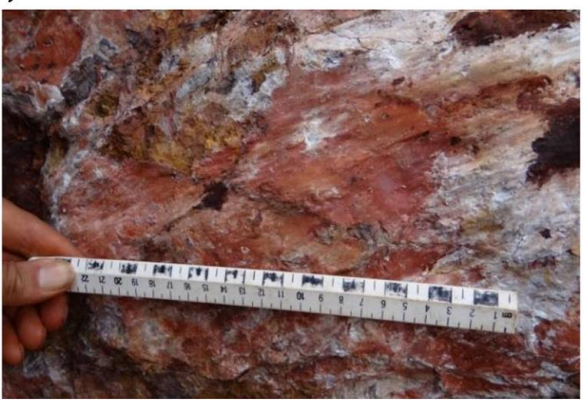

(h)

Figure 5. Examples of shear zones in the Kukuluma terrain: (a) Closely spaced magnetite-bearing sheeted quartz veins intruded along a $\mathrm{D}_{1}$ shear zone (Kukuluma pit); (b) Planar chert ridge (right) cuts at a low-angle through primary bedding in a meta-ironstone unit along access road to Kukuluma. The chert is interpreted as a $\mathrm{D}_{1}$ shear zone; (c) Planar chert horizon east of Area 3. The margin of the chert parallels $S_{0}$ in the surrounding sediments, but internally the chert is folded with mylonitic characteristics attributed to $\mathrm{D}_{1} ;$ (d) $\mathrm{D}_{5}$ low-angle reverse fault and associated recumbent folding in chert in Kukuluma pit; (e) Cataclasite and tectonic breccia zone along the $\mathrm{D}_{6}$ shear zone in chert in Kukuluma pit; (f) $\mathrm{D}_{6}$, Kasata shear in the northwest corner of the Matandani pit; (g) $\mathrm{D}_{7}$ fracture plane characterized by the presence of (white) sericite and sulphide alteration in artisanal workings along the western wall of Matandani pit; (h) $\mathrm{D}_{7}$ fracture plane with (white) sericite and slickenlines indicative of normal-sinistral movement in artisanal workings along the western wall of the Matandani pit. 
Similar discordant chert horizons displaying complex internal folding and fine-grained fabrics with mylonitic affinities are common throughout the central Kukuluma terrain. In many places (e.g., Figure 5b) the chert layers transect bedding in the surrounding meta-ironstone or meta-greywacke units at a low angle. In other places, the orientation of chert beds is parallel to layering within the wall rock (Figure $5 \mathrm{c}$ ). On a regional scale, the chert bands form low ridge lines that can be traced for several kilometers (Figure 3). The chert horizons display sudden thickness variations along the strike, and in places bifurcate or merge to form anastomosing patterns. The chert bands are affected by all later folding events described below, and formed early in the tectonic history of the Kukuluma terrain.

\section{2. $D_{2}-D_{3}$ Folding and Shearing}

The composite $S_{1} / S_{0}$ fabric in the central Kukuluma terrain was folded and sheared during $D_{2}$ and $\mathrm{D}_{3}$ events (Figures 6-8). This has resulted in locally complex, $\mathrm{D}_{2}-\mathrm{D}_{3}$ interference folding of the volcano-sedimentary stratigraphy, including those units that preferentially host gold mineralization.

$\mathrm{F}_{2}$ folds occur on outcrop scale as tight to isoclinal folds that develop a penetrative axial planar cleavage in fine-grained shale. $\mathrm{F}_{2}$ fold axes are highly variable in orientation (Figure 6), in part due to the non-cylindrical nature of $\mathrm{D}_{2}$ folds [24], and in part due to later folding overprints causing regional (domainal) variability in the $\mathrm{D}_{2}$ fold axes. In single outcrops, where $\mathrm{F}_{2}-\mathrm{F}_{3}$ interference folding is well-developed (e.g., Figure 8), the orientation of $\mathrm{F}_{2}$ fold axes varies from near-parallelism with $F_{3}$ fold axes, to high angles, to $F_{3}$ fold axes-a trend reflected in stereoplots of $F_{2}$ (Figure 6). The existence of large-scale $(>100 \mathrm{~m}) \mathrm{D}_{2}$ folds is evident from the regional distribution patterns of chert ridges (Figure 3), and can also be inferred from the domainal distribution of $\mathrm{D}_{3}$ fold axes orientations (Figure 6), as explained below.

$\mathrm{D}_{3}$ folds are common, and comprise upright to vertical folds that vary from open to near-isoclinal, with tightening of the folds occurring near planar high strain zones. The $S_{3}$ axial planar surface is generally near vertical, and varies in trend from west to northwest, with orientations in the pits showing two clear maxima around 210/80 and 350/75 (Figure $6 c$ ) as a result of $\mathrm{D}_{4}$ folding (discussed below). $S_{3}$ fabrics vary in character, from well-developed, closely spaced $(<1 \mathrm{~mm})$, planar crenulation cleavages in shale (Figure 7c), to more widely spaced fracture cleavages in more competent silicified meta-ironstone beds.

The orientation of $F_{3}$ fold axes varies in a systematic manner across the pits, as a result of $D_{2}-D_{3}$ fold interference (Figure 6). Along the southern wall and western ramp of Kukuluma pit, $\mathrm{F}_{3}$ fold axes generally plunge shallowly eastward (ave. $F_{3}=091 / 17$; Figure $6 c$ ). Towards the north wall of the Kukuluma pit, $F_{3}$ fold axes rotate to near-vertical (ave. $F_{3}=287 / 83$; Figure $6 c$ ). The same near-vertical $\mathrm{D}_{3}$ fold orientation also dominates outcrops in the area between the Kukuluma and Matandani pits, and in the southwestern wall of the Matandani pit. Towards the northeastern wall of the Matandani pit, $\mathrm{F}_{3}$ fold axes vary between a near vertical plunge and a gentle northwest-southeast plunge (Figure $6 \mathrm{c}$ ). The bimodal distribution of the $\mathrm{F}_{3}$ fold axes indicates that large-scale $\mathrm{D}_{2}$ folds are present, with the hinge zone of one such fold trending in a general northeastern direction along the northwest margin of Kukuluma pit, and a possible second $\mathrm{F}_{2}$ hinge zone passing through Matandani pit. Before upright $D_{3}$ folding, the orientation of the composite $S_{0} / S_{1}$ layering would have varied from steeply north to northwest, dipping into the southern part of the Matandani pit and the area between Matandani and Kukuluma pits, to generally shallow dipping layering in most of the Kukuluma pit and in the northern part of the Matandani pit. This pattern suggests the presence of a $500 \mathrm{~m}$ scale, possibly southeast verging, asymmetric, antiformal $\mathrm{D}_{2}$ fold, with a northwest-dipping axial planar surface.

Outcrop scale vergence of $\mathrm{D}_{3}$ folds varies across the pits, reflecting large-scale $\mathrm{D}_{3}$ folding. Along the southern and western walls of the Kukuluma pit, $\mathrm{D}_{3}$ folds generally verge northward, whereas the $\mathrm{D}_{3}$ folds along the northern wall of the pit verge southward. This suggests that the Kukuluma pit is positioned in the centre of a $500 \mathrm{~m}$ scale, east to southeast trending, upright $\mathrm{D}_{3}$ fold, and occurs together with the Matandani pit along the hinge zone of a large-scale $\mathrm{D}_{3}$ anticlinorium. 
$\mathrm{D}_{2}-\mathrm{D}_{3}$ fold interference patterns are common on an outcrop-scale (e.g., 0418140-9688080; Figure 8), and are generally of Type $2[45,46]$. Interference patterns are characterized by crescent and hook shapes (Figure 8), and locally converge to Type 3 fold patterns, where $F_{2}$ and $F_{3}$ fold hinges reach near-parallelism [45]. Around Area 3, chert ridges define 500-800 m scale Type 2 fold interference patterns (Figure 3).

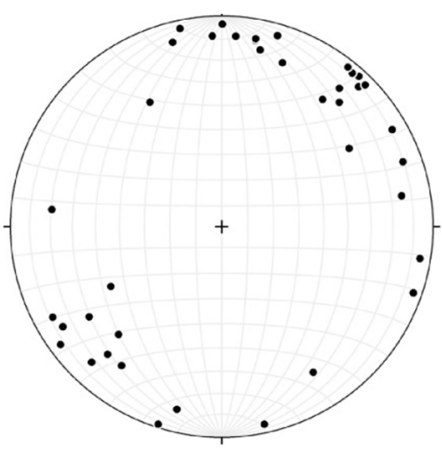

(a)

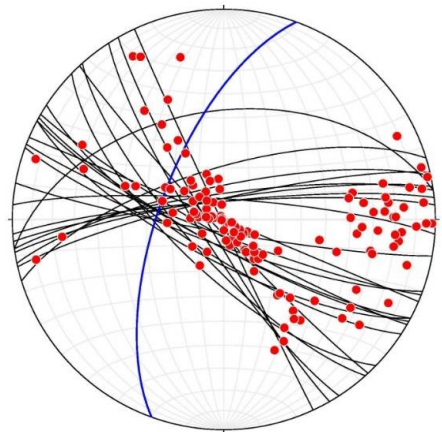

(d)

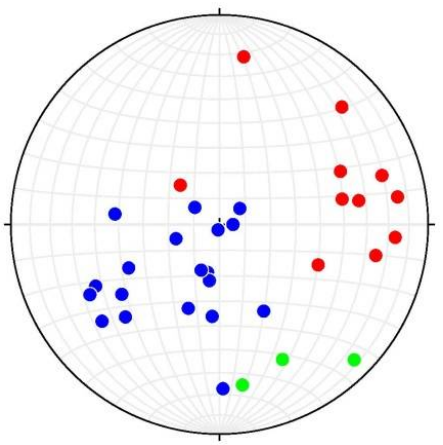

(b)

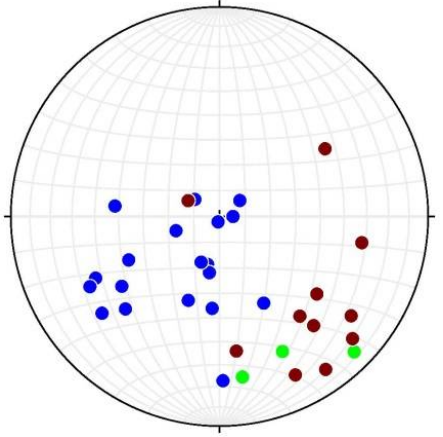

(e)

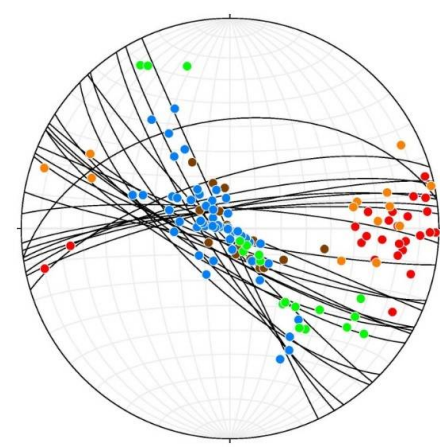

(c)

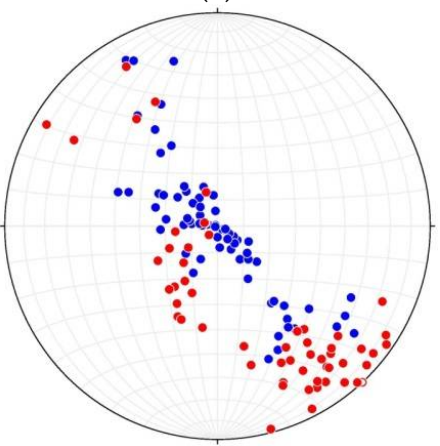

(f)

Figure 6. (a) Orientation of poles to the intrusive diorite-sediment contacts, as observed in the drill core and the field $(N=38)$; (b) Orientation of $\mathrm{F}_{2}$ fold axes in Kukuluma and Matandani pits $(N=33)$. Colour coding: red = southern ramp in the Kukuluma pit; blue = southwest side in the Matandani pit; green = northeast side in the Matandani pit; (c) Orientation of $S_{3}$ fold axial planes (great circles) and $F_{3}$ fold axes in the Kukuluma and Matandani pits. Colour coding: red = southern ramp in Kukuluma pit; orange $=$ western ramp in Kukuluma pit; brown = northwest wall in Kukuluma pit; blue = southwest side in Matandani pit; green = northeast side in Matandani pit; (d) Orientation of $\mathrm{S}_{3}$ fold axial planes (great circles) and $\mathrm{F}_{3}$ fold axes (red dots) in the Kukuluma and Matandani pits. $\mathrm{S}_{3}$ and $\mathrm{F}_{3}$ are distributed in two clusters in either limb of $\mathrm{D}_{4}$ folds. $\mathrm{S}_{4}$ (blue great circle) equals the plane bisecting the obtuse angle $=290 / 65$; (e) Orientation of $F_{2}$ fold axes in Kukuluma and Matandani pits, in which the Kukuluma axes have been rotated clockwise by 50 degrees around an axes of 287/65, to remove the effects of $\mathrm{D}_{4}$ open folding. Colour coding: brown = rotated orientations along the southern ramp in the Kukuluma pit; blue = southwest side in the Matandani pit; green = northeast side in the Matandani pit; (f) Orientation of $\mathrm{F}_{3}$ fold axes in Kukuluma and Matandani pits, in which the Kukuluma axes have been rotated clockwise by 50 degrees around an axes of $287 / 65$, to remove the effects of $\mathrm{D}_{4}$ open folding. Colour coding: red = rotated $\mathrm{F}_{3}$ orientations in Kukuluma pit; blue $=\mathrm{F}_{3}$ orientations in Matandani pit.

Locally, $\mathrm{D}_{2}-\mathrm{D}_{3}$ fold domains are truncated by planar foliation domains that are unaffected by $\mathrm{D}_{2}-\mathrm{D}_{3}$ folding, except for the presence of isoclinal intrafolial folds within the foliation. Good examples can be seen along the southeast wall of the Matandani pit (e.g., 418180-9688300). These foliation domains trend northwest across the central Kukuluma terrain, and are generally near-vertical. The domains contain a moderate to steep west to northwest plunging mineral lineation, $\mathrm{L}_{3}$, which parallels the axes of intrafolial folds within the high strain domains. The layering in these 
foliation domains is composite in nature with $S_{0} / S_{1} / S_{2} / S_{3}$, all transposed and parallel to each other, and they developed at the same time as the $\mathrm{D}_{3}$ folding. The regional distribution of these $\mathrm{D}_{3}$, high-strain zones cannot be assessed, due to poor outcrop exposure.

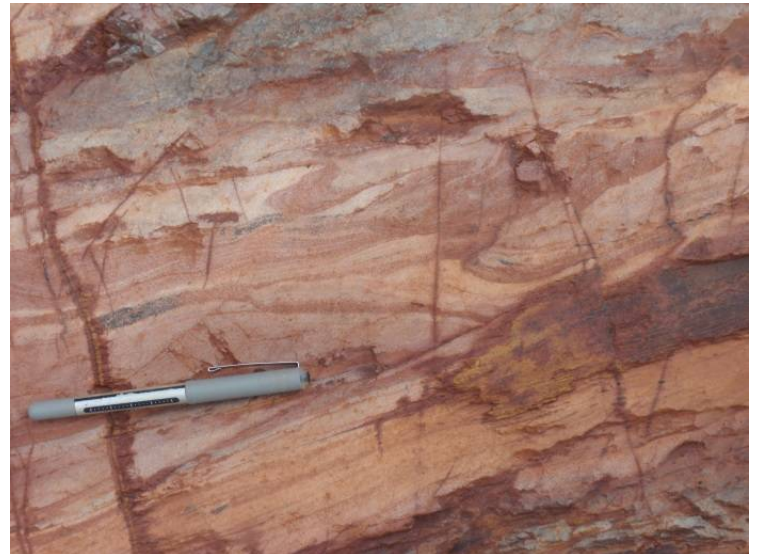

(a)

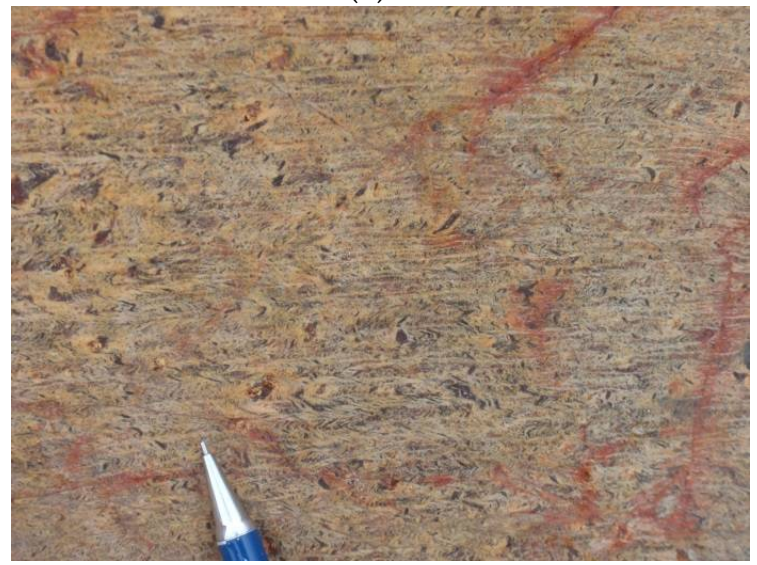

(c)

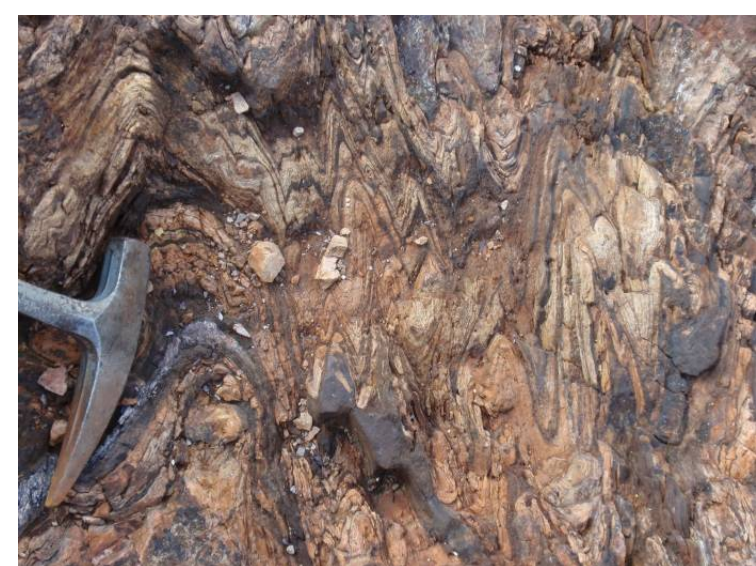

(b)

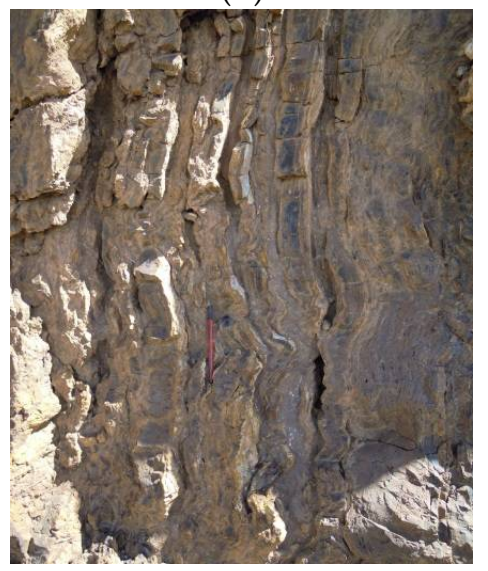

(d)

Figure 7. Examples of fold structures in the central Kukuluma terrain: (a) Ductile, flame-like isoclinal folds in turbiditic greywacke, interpreted as folding associated with fluidization during $\mathrm{D}_{1}$; (b) Tight $\mathrm{D}_{3}$ vertical folds in ironstone in the southwest Matandani pit; (c) Close up of $\mathrm{S}_{3}$ spaced crenulation cleavage in shale; (d) Open recumbent $\mathrm{D}_{5}$ folding in chert bands.

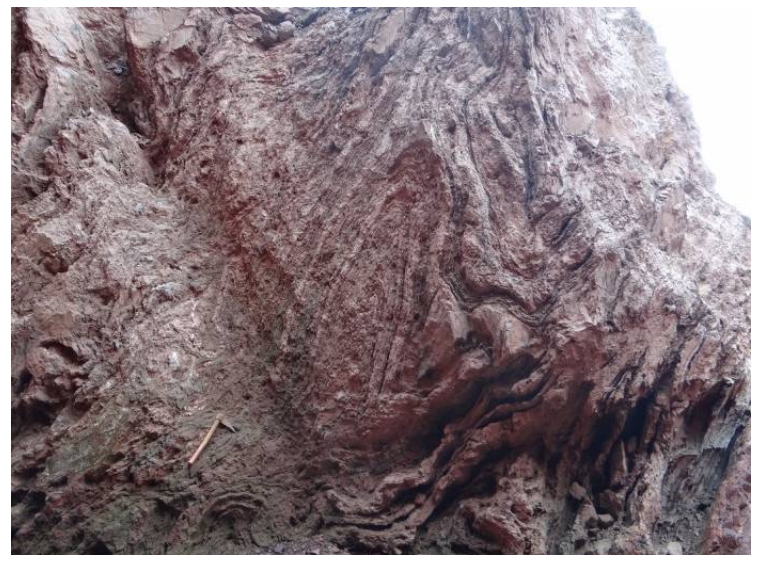

(a)

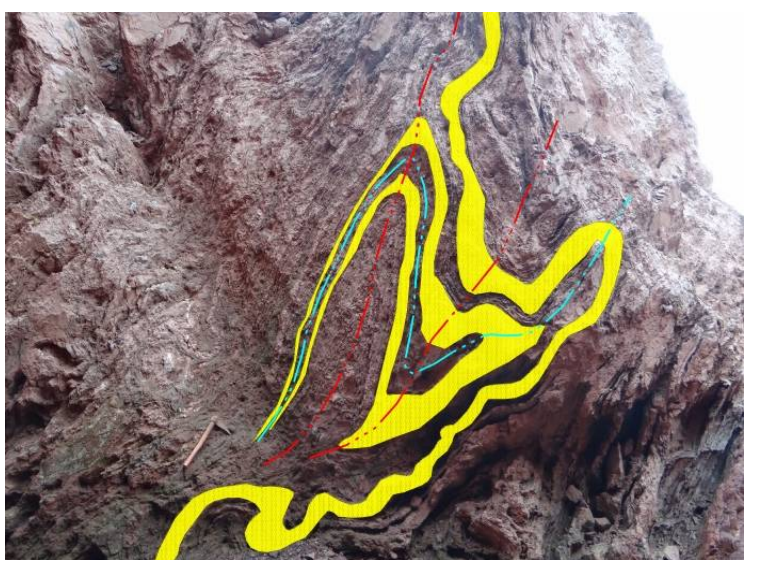

(b)

Figure 8. Cont. 


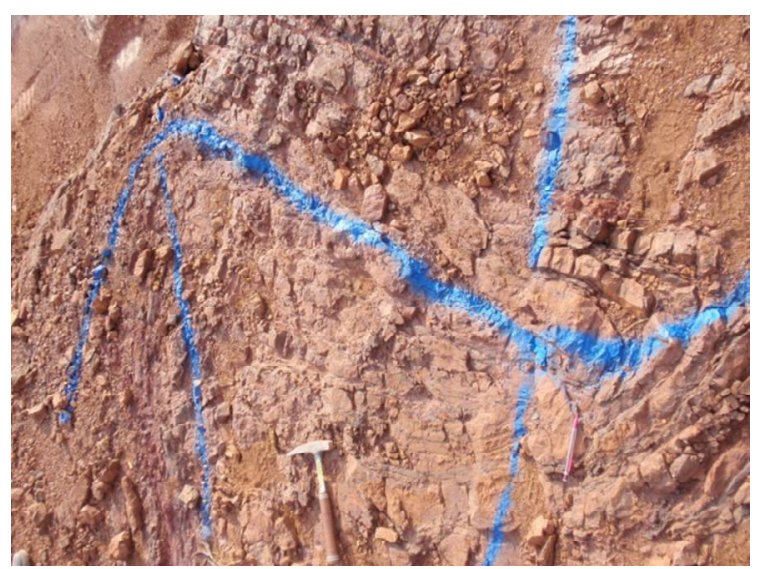

(c)

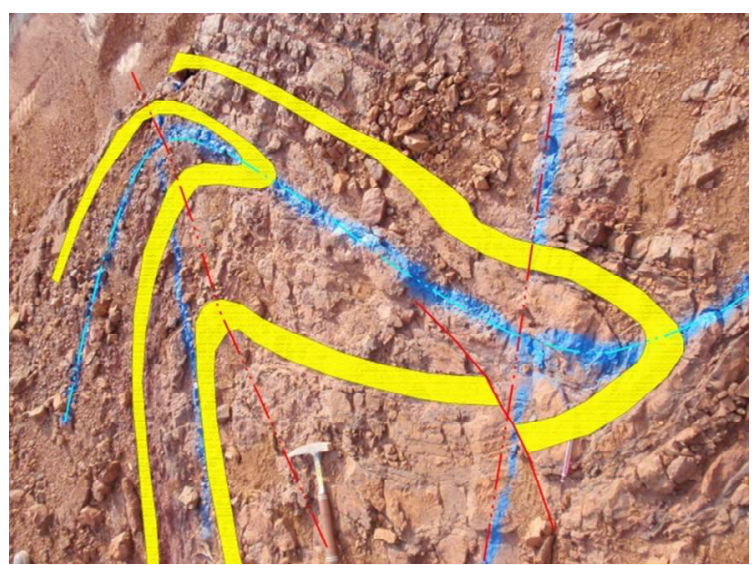

(d)

Figure 8. Examples of outcrop-scale $\mathrm{D}_{2}-\mathrm{D}_{3}$ fold interference patterns in the central Kukuluma terrain, shown as annotated pairs. Marker layers have been highlighted in yellow; the $\mathrm{D}_{2}$ fold axial trace is shown in light blue; the $\mathrm{D}_{3}$ fold axial trace is shown in red. $(\mathbf{a}, \mathbf{b})$ Vertical view of fold pair in erosion gully along the eastern face of Matandani pit; (c,d) Horizontal view of fold pair on the upper benches in the southwest corner of Matandani pit.

\section{3. $D_{4}$ Gentle Upright Folding}

$\mathrm{D}_{4}$ folds are gentle, cylindrical, upright folds, with steep axial planes that warp $\mathrm{S}_{3}$ (and earlier foliations) on a $0.5-1 \mathrm{~km}$ scale. $\mathrm{D}_{4}$ folds are not clearly visible in the outcrop, but can be seen when tracing $D_{1}$ chert horizons or $S_{3}$ along strike; e.g., across Kulkuluma pit $S_{3}$ orientations changing from steeply southwest-dipping (ave. 210/80) in the northwest corner of the pit to steeply north-dipping (ave. 350/75) across the rest of the pit, as a result of large-scale, $\mathrm{D}_{4}$ folding, with steeply western-plunging fold axes and a northwest-dipping fold axial plane (Figure 6d). Similar open folding of $\mathrm{D}_{3}$ structures is apparent across the area (Figure 3), with the fold axial trace of $\mathrm{D}_{4}$ folds trending roughly north-northeast-south-southwest. No penetrative $\mathrm{S}_{4}$ fabric has developed, but where $\mathrm{D}_{4}$ folds affect thick chert layers, e.g., around Area 3, a spaced north-northeast-trending fracturing can be observed in $\mathrm{D}_{4}$ hinge zones.

\section{4. $D_{5}$ Recumbent Folding and Low-Angle Reverse Faulting}

$\mathrm{D}_{5}$-involved, localized, low-angle reverse faulting and associated recumbent folding is poorly visible in areas without good vertical exposure. Low-angle reverse fault planes are best developed within the well-bedded ironstone units in the west side of the Kukuluma pit (Figure 5d). Fault zones vary in thickness from several $\mathrm{mm}$ to $\sim 20 \mathrm{~cm}$, but are generally thin and discrete, and visible as thin grey clay zones that ramp up through the ironstone units. The larger (i.e., wider) fault zones generally dip gently north (around 000/20), but they vary locally in orientation, with secondary fractures moving into parallelism with bedding planes. The faults accommodated reverse movements of up to $\sim 10 \mathrm{~m}$, with most faults accommodating significantly less.

Folding is common in spatial association with the fault planes. $\mathrm{D}_{5}$ folds vary in scale from $0.1-5 \mathrm{~m}$, and are generally open recumbent folds with near-horizontal to shallowly dipping axial planar surfaces (Figures $5 \mathrm{~d}$ and $7 \mathrm{~d}$ ), and shallowly east- or west-plunging fold axes. In some places, $\mathrm{D}_{5}$ folds are asymmetric, and appear as drag folds associated with the thrusts (Figure $5 \mathrm{~d}$ ). Elsewhere, $\mathrm{D}_{5}$ folds form open corrugations in well-bedded meta-ironstone, with widely spaced fracture cleavages. 


\section{5. $D_{6}$ Brittle-Ductile Shear Zones}

A network of generally steeply dipping, northwest- to west-northwest-trending shear zones can be traced across the central Kukuluma terrain (Figure 3). These $\mathrm{D}_{6}$ shears crosscut the folded sequence, and have been linked to mineralization $[47,48]$. In the Kukuluma and Matandani pits the system of $\mathrm{D}_{6}$ shear zones is referred to as the Juma and Kasata shear zones (Figure 3b; [47]. In Area 3, similar westto northwest-trending shear zones can be seen in the drill core, but poor outcrop prevents these shears from being mapped.

The Juma shear zone can be traced along the entire length of the Kukuluma and Matandani pits, and occurs within the small open pit between Kukuluma and Matandani (Figure 3b). The shear zone is positioned along the west-northwest- to northwest-trending northern contact of a major intrusive diorite sill belonging to the KIC (Figure 3b; [28]). Towards the eastern end of the Kukuluma pit, the Juma shear terminates into a network of smaller, moderately- to steeply-dipping fracture zones with variable trends (Figure $3 b$ ).

The Kasata shear zone can be traced through the centre of the Kukuluma pit as a composite, steeply-dipping, and generally west- to west-northwest-trending fracture zone. In Matandani pit, the shear zone re-appears in the south corner of the pit as several west-northwest-trending, semi-parallel fracture zones that merge towards the northwestern part of the pit, into a single northwest-trending brittle-ductile shear zone, which follows the contact of the same intrusive diorite bordering the Juma shear (Figure 3b). In the eastern part of Kukuluma pit, the Juma and Kasata shears merge across a complex network of mostly east-west trending fractures.

Individual $\mathrm{D}_{6}$ shear planes are accompanied by damage zones up to several meters in width, which are associated with secondary jointing, brecciation, veining, and silicic alteration. Mineralization occurs mainly as disseminated sulphide impregnations along microfractures in the damage zones. Where several shear planes are in close proximity to one another (e.g., in the south corner of the Matandani pit, or where the Kasata and Juma shears merge in the eastern part of the Kukuluma pit), extensively fractured and altered (strongly silicificied) domains occur, up to $15 \mathrm{~m}$ wide. Where the shears transect micaceous schist, chlorite-muscovite shear bands have developed into S-C-like fabrics (e.g., Figure 5f). Brittle deformation structures (veins, breccia, and cataclasite zones) are more common in portions where the shear zone cuts across massive, chert-rich meta-ironstone units (Figure 9). $\mathrm{L}_{6}$ lineations are visible as mineral alignments, striations, and quartz rods. In places, mineralization appears to be concentrated along $\mathrm{D}_{6}$ shear zones, but elsewhere (e.g., the northwest and south walls of the Matandani pit and the northeast corner of Kukuluma pit), well-exposed portions of the $\mathrm{D}_{6}$ shears are not mineralized.

The orientations of the $\mathrm{D}_{6}$ fracture zones associated with the Juma and Kasata shears, as measured in the Kukuluma pit, are shown in Figure 9a. The main strands of the Juma and Kasata shears trend west-northwest $(020 / 80)$, with a gently northwestern- or southeastern-plunging lineation recording a dextral sense of movement with a reverse component. A prominent set of second-order shears trends more northwest, with a steep southwest dip (average 235/75) and a moderately south-plunging lineation recording reverse dextral movements. A third set of steeply north-northwestto northwest-dipping shear zones (average 324/72), with moderately to steeply north-plunging lineations record sinistral-reverse movements; in addition, a fourth set of steeply south-dipping, east-west trending faults (average 175/76) host down dip lineations and a pure reverse (south over north) sense of movement (Figure 9a). This network of shears is generally non-mineralized, and is consistent with Y-shears (the Juma shear), Riedel shears (northwest-trending set) and anti-Riedel shears (southwest-trending set) within a wider dextral transpressional shear system [46], which combines with high-angle reverse faults (the east-trending set). On a larger scale, the distribution of the main $\mathrm{D}_{6}$ shear zones is reminiscent of a right-stepping en-echelon array of west-northwest- to northwest-trending shears within a more east-west trending shear envelope, accommodating reverse dextral movement (Figure 3). 


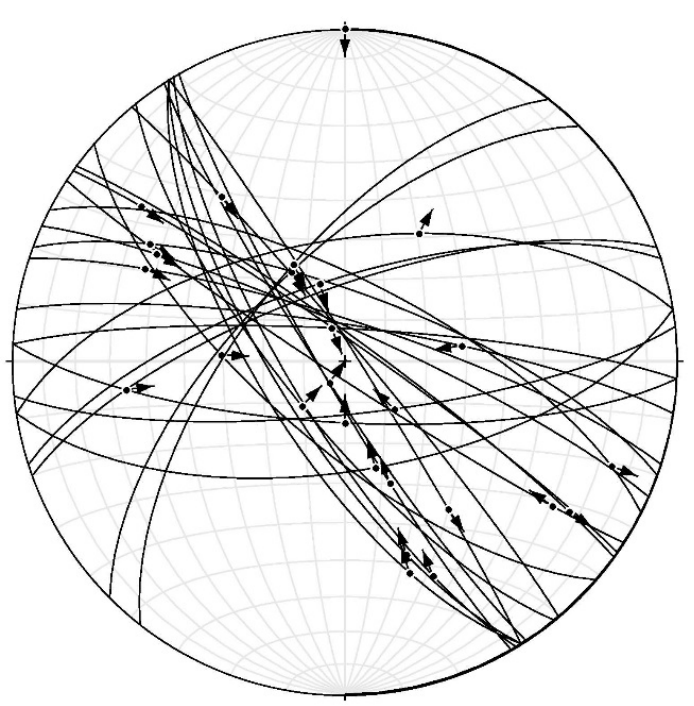

(a)

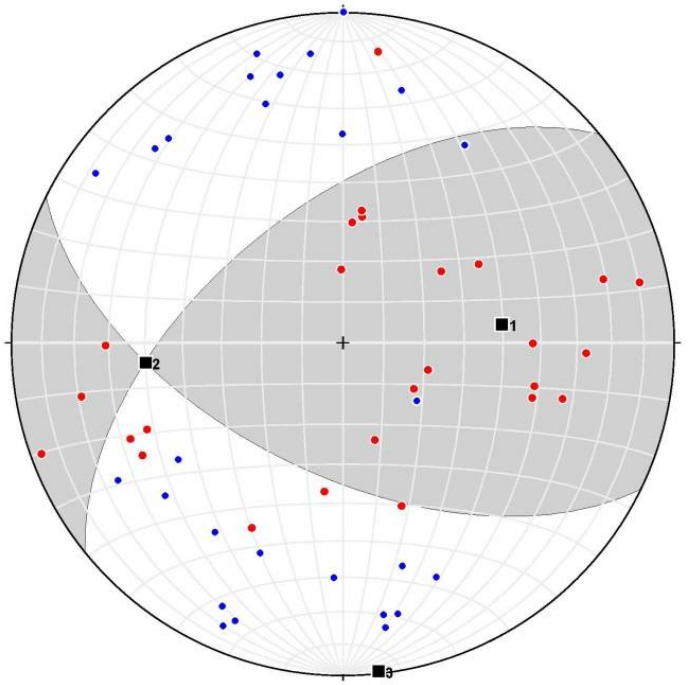

(b)

$\begin{array}{rrrc}\text { Bingham solution: Axis } & \text { Eigenvalue } & \text { Trend } & \text { Plunge } \\ \text { 1. }\left(\sigma_{3}\right) & 0.1918 & 083.1 & 50.2 \\ \text { 2. }\left(\sigma_{2}\right) & 0.0419 & 264.5 & 39.8 \\ \text { 3. }\left(\sigma_{1}\right) & 0.2337 & 173.9 & 00.7\end{array}$

Figure 9. Orientation and paleo-stress analysis for $\mathrm{D}_{6}$ shear zones measured in the Kukuluma and Matandani pits $(N=27)$. (a) Plot of fault planes and lineations, with arrows pointing in the direction of movement of the hanging wall; (b) Fault plane solution (Bingham matrix solution) for the measured $\mathrm{D}_{6}$ faults (compression dihedron in white; tension dihedron in grey). $P$ axes are shown in blue, $T$ axes in red. The Bingham solution shows north-south shortening with a near-horizontal $\sigma_{1}$, and a dispersed distribution of the $P$ and $T$ axes, i.e., $\sigma_{2}$ and $\sigma_{3}$ are similar.

A paleo-stress analysis for the $D_{6}$ faults in Kululuma and Matandani pits using Faultkin $[18,49,50]$ was performed on 27 shear planes, for which kinematic data was obtained. These shear zones are part of the interconnected network of fractures that form the Juma and Kasata shear network (Figure 3), and hence it is assumed that they formed simultaneously in response to the same far field stress [18]. In doing the analysis, all shear planes were given the same weight; the methodology to conduct paleo-stress analysis has been explained in Appendix A. Results are shown in Figure 9b, and indicate that the $\mathrm{D}_{6}$ shear zones in the central Kukuluma terrain formed in response to horizontal, near north-south shortening, in a plane-strain to flattening-strain environment $(\operatorname{Rev}=0.35)$.

\section{6. $D_{7}$ Faulting}

Where $\mathrm{D}_{6}$ shear zones are outcropping, they commonly show evidence of reactivation along discrete, $m m$-wide, $\mathrm{D}_{7}$ fracture surfaces that are slickensided, with slickenfibres defined by sericite or quartz (Figure $5 \mathrm{~g}, \mathrm{~h}$ ). Reactivation of $\mathrm{D}_{6}$ shear zones during $\mathrm{D}_{7}$ is most clearly demonstrated in Matandani pit, where a north-trending porphyry dyke dated at $2651 \pm 14 \mathrm{Ma}$ [28] transects the $\mathrm{D}_{6}$ shear fabric, but is fractured and displaced by several centimeters, as a result of brittle reactivation along $D_{7}$ fractures that formed as discrete planes in the center of the $D_{6}$ shear zone. Where the $D_{7}$ fractures cut the dyke, an alteration halo of quartz-sericite-sulphide has developed, and the dyke is mineralized. The $D_{7}$ fracture planes contained as reactivation surfaces in $D_{6}$ shear zones are generally associated with lineation directions that record a normal sense of movement. A network of well-developed $D_{7}$ fracture planes can be seen in the eastern corner of the Kukuluma pit, where they occur near the termination of the Juma shear, and where they are highlighted by artisanal miners who have excavated high-grade mineralization along the fracture planes. 
Away from $D_{6}$ shear zones, narrow fracture zones attributed to $D_{7}$ occur in parts of the pits and in Area 3 (Figure 5g,h). Such fractures are mineralized with disseminated sulphide (mainly pyrite) alteration of the wall rocks, and they have the appearance of (shear) joints. The fractures are locally paralleled by thin grey quartz stringers, which return free gold in pan.

In the western wall of the Matandani pit, three 15-20 m wide, $D_{7}$ fracture zones occur to the west of the Kasata shear zone, within deeply weathered, layered turbiditic meta-sediment and ironstone. Each fracture zone comprises an interconnected network of variably orientated fractures, within envelopes that trend roughly $290-110^{\circ}$. The three fracture zones are arranged in an en echelon array along a northwest trend. Within each fracture zone, individual fractures have maximum strike lengths of several tens of meters, but most are shorter in length. The fractures are narrow $(<3 \mathrm{~mm})$ and characterized by sericitic alteration (now mostly visible as white clay staining) with disseminated sulphide (cubic pyrite, now mostly oxidized).

The fault planes preserve excellent slickenlines and shear sense indicators, indicative of predominantly sinistral normal movement (Figure 5h). Displacements on the $D_{7}$ fracture planes are small, i.e., in the order of centimeters. To the southeast, along the floor of the Matandani pit, where the east-southeast-trending envelope of the fracture planes transects the Kasata shear along the contact of ironstone and diorite, the main ore zone occurs that is targeted by Geita mine (Figure 3).

Paleo-stress analyses for the $\mathrm{D}_{7}$ fracture zones in Kululuma and Matandani pits using Faultkin $[18,49,50])$ was performed on 53 fracture planes, for which kinematic data was obtained. These fractures are all part of interconnected fracture zones targeted by artisanal workers, and are associated with the same sericite-sulphide alteration, and hence it is assumed that they formed simultaneously in response to the same far field stress. In doing the analysis, all fracture planes were given the same weight (Appendix A). Results are shown in Figure 10, and indicate that $\mathrm{D}_{7}$ shear zones in the central Kukuluma terrain formed in response to a horizontal, north-northeast extension in a plane strain environment.

(a)

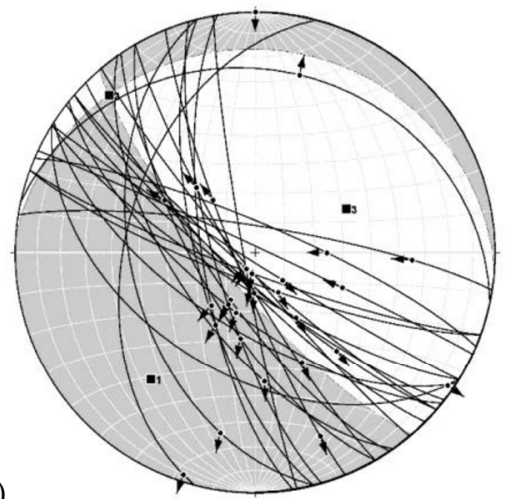
Axis
1. $\left(\sigma_{3}\right) \quad 0.3361$
Trend
Plunge
2. $\left(\sigma_{2}\right) \quad 0.0356$
217.8
3. $\left(\sigma_{1}\right)$
0.3717
32.5
12.2
$063.5, \quad 54.7$

(b)

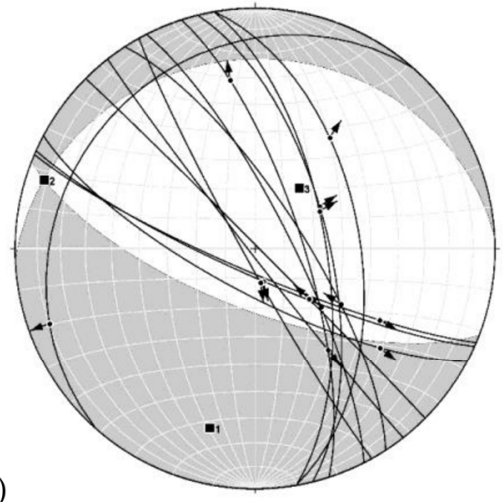
Axis Eigenvalue Trend Plunge
$\begin{array}{llll}\text { 1. }\left(\sigma_{3}\right) & 0.2589 & 194.3, & 23.9\end{array}$
2. $\left(\sigma_{2}\right) \quad 0.0660 \quad 288.0, \quad 08.3$
3. $\left(\sigma_{1}\right) \quad 0.1929 \quad 035.8, \quad 64.5$

Figure 10. Cont. 
(c)

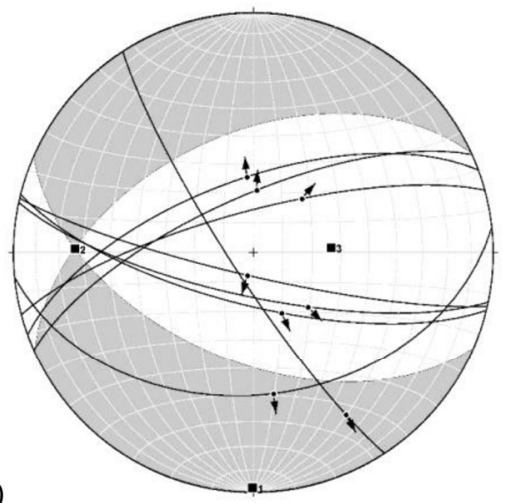

$\begin{array}{lccl}\text { Axis } & \text { Eigenvalue } & \text { Trend } & \text { Plunge } \\ \text { 1. }\left(\sigma_{3}\right) & 0.3299 & 180.3, & 02.0 \\ \text { 2. }\left(\sigma_{2}\right) & 0.0011 & 271.3, & 26.4 \\ \text { 3. }\left(\sigma_{1}\right) & 0.3288 & 086.2, & 63.5\end{array}$

(d)

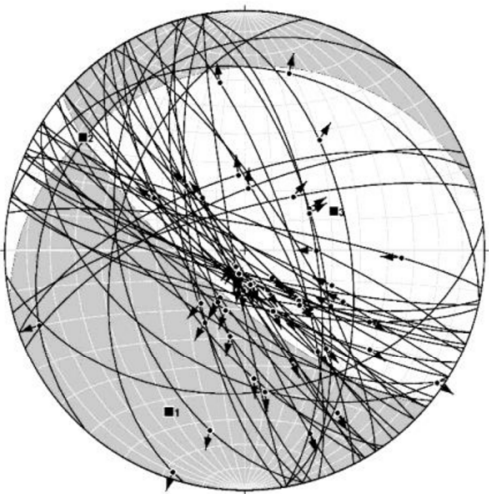

$\begin{array}{lccc}\text { Axis } & \text { Eigenvalue } & \text { Trend } & \text { Plunge } \\ \text { 1. }\left(\sigma_{3}\right) & 0.2856 & 205.2, & 26.5 \\ \text { 2. }\left(\sigma_{2}\right) & 0.0261 & 304.9, & 18.7 \\ \text { 3. }\left(\sigma_{1}\right) & 0.3117 & 065.9, & 56.7\end{array}$

Figure 10. Orientation and paleo-stress analysis for $D_{7}$ fracture arrays measured in the Kukuluma and Matandani pits. For each area, the plot shows the fault planes as great circles and the lineations as arrows that point in the direction of movement of the hanging wall; these are placed on top of the fault plane solution (Bingham matrix solution) for the measured $\mathrm{D}_{7}$ faults (compression dihedron in white; tension dihedron in grey). The Bingham solutions for each data set are shown below the stereoplots. (a) West wall of Matandani pit $(N=30)$; (b) Northeast wall of Matandani pit $(N=13)$; (c) East wall of Kukuluma pit $(N=8)$; (d) All measurements from Kukuluma and Matandani pits combined $(N=51)$. All plots show north-south to northeast-southwest extension with a steep $\sigma_{1}$, and near horizontal $\sigma_{2}$ and $\sigma_{3}$ orientations.

Similar $\mathrm{D}_{7}$ fractures are also targeted by artisanal miners in Area 3, where many are decorated by stringers of thin $(<1 \mathrm{~cm}$ wide) grey quartz containing visible gold. The larger scale distribution of the $\mathrm{D}_{7}$ faults, beyond the pit areas is not clear, because the structures are subtle and not exposed beyond the workings of artisanal miners.

\section{The Timing of Intrusions and Breccia Formation during Deformation}

\subsection{The Emplacement of Intrusions during Deformation}

Deformation events were accompanied by the emplacement of two separate suites of syn-tectonic intrusions, one dioritic to monzonitic in composition, and a second granodioritic in composition that manifests itself as a first generation of porphyry dykes and sills. These intrusions are collectively called the Kukuluma Intrusive Complex (KIC; [26]) and they occur across the central part of the Kukuluma terrain (Figure 3), where they were emplaced between 2715-2665 Ma [28]. They have been overprinted by a second generation of granodioritic porphyry dykes, emplaced around $2650 \mathrm{Ma}$ [28].

The diorite-monzonite suite of the KIC is dominated by equigranular, fine- to medium-grained, sheet-like bodies, stocks of diorite and plagioclase-rich porphyritic diorite dykes of irregular thickness (e.g., northwest corner of the Kukuluma pit), which locally form interconnected networks that both transect and parallel bedding (Figure 3). The granodiorite suite comprises thin ( $<2 \mathrm{~m}$ wide) dykes with porphyritic textures that occur in a variety of orientations (steeply dipping dykes with west, north-northwest, and north trends have been observed) [26].

The intrusive bodies belonging to the diorite-monzonite suite are weakly to moderately foliated as a result of $\mathrm{D}_{3}$ deformation. In places, intrusive margins and vein systems internal to the intrusions are folded during $\mathrm{D}_{3}$ (e.g., 0418900-9687780). More commonly, intrusions form sheet-like bodies that were emplaced along axial planar orientations of $D_{3}$ folds, with intrusive contacts cutting through $\left(D_{3}\right)$ folded meta-sedimentary sequences, whilst foliations parallel to $S_{3}$ develop within the intrusions. In the 
southwestern part of Matandani pit, rafts of $\mathrm{D}_{3}$ folded meta-ironstone occur within an intrusive diorite body that is foliated in an orientation parallel to $S_{3}$. Nowhere did we see diorite or monzonite intrusions being folded around $\mathrm{D}_{2}$ structures, but the intrusions are affected by $\mathrm{D}_{4}$ folding. Plagioclase-rich, porphyritic diorite dykes that form part of the diorite-monzonite suite cut through more massive diorite bodies, and are foliated. Where these dykes cut through meta-sediment, and especially $\mathrm{D}_{3}$ planar high strain zones, they can be slightly folded as a result of $\mathrm{D}_{3}$.

The field relationships indicate that the diorite-monzonite suite was emplaced after $\mathrm{D}_{2}$, but immediately before and during $\mathrm{D}_{3}$. The porphyritic granodiorite dykes of the KIC are not foliated, and intrude into the diorite and monzonite bodies within the Kukuluma and Matandani pits. The exact relationship of these dykes with $D_{5-6}$ shear zones is not clear, but they appear largely unaffected by these events. Two granodiorite dykes and a small granodiorite intrusion belonging to this suite of intrusion yield U-Pb zircon ages of $2667 \pm 17 \mathrm{Ma}, 2661 \pm 16 \mathrm{Ma}$, and $2663 \pm 11 \mathrm{Ma}$ [28].

A second generation of felsic porphyry dykes of granodioritic composition, represented by a single, north-trending, 1-2 m wide, porphyritic felsic dyke transects the Matandani pit (Figure 3b). The dyke has chilled margins and no internal fabric, and cuts through $\mathrm{D}_{1}-\mathrm{D}_{6}$ structures. Where this dyke cuts through the Juma and Kasata shears, it can be seen to transect $\mathrm{D}_{6}$ fabrics. However, the dyke is cut by narrow $D_{7}$ fracture planes, associated with slickensides, a sinistral normal sense of movement with limited displacement $(<5 \mathrm{~cm})$, and alteration, including sulphide growth and gold mineralization, i.e., the timing of emplacement of this dyke is post- $\mathrm{D}_{6}$, but pre- $\mathrm{D}_{7}$ and pre-mineralization (Table 1). This dyke yields a zircon age of $2651 \pm 14 \mathrm{Ma}$ [28], which provides a maximum age constraint to mineralization.

\subsection{Syn-Tectonic Brecciation Events}

Parts of the folded meta-sedimentary sequences in the Kukuluma and Matandani pits have been brecciated. In Kukuluma pit, breccia zones are largely restricted to the western wall of the pit, and occur as elongated bodies, 5-50 m thick, covering the entire height of the pit wall. The zones occur within the strongly $\mathrm{D}_{2}-\mathrm{D}_{3}$ folded package of meta-ironstone units, with clasts consisting mostly of chert embedded in a more micaceous and feldspar-rich matrix, in close spatial association with the intrusive dykes and stocks of the KIC. In the Matandani pit, extensive brecciation occurs in the southwest part of the pit, within strongly $\mathrm{D}_{2}-\mathrm{D}_{3}$ folded meta-ironstone intercalated with micaceous and graphitic shale, and concentrated along the western contact of a diorite intrusion that transects the centre of the pit (Figure 3b). Outside the open pits, a major breccia body $(\sim 100 \times 50 \mathrm{~m}$ in size $)$ occurs to the northwest of Matandani pit (Figure 3a).

Breccia varies from crackle breccia, in which blocks have a jigsaw fit and the underlying folds and layering are preserved in a semi-coherent manner (Figure 11a), to massive chaotic breccia in which the primary layering is destroyed (Figure 11b). The change from jigsaw breccia to chaotic breccia is gradational, and along the western wall of Kukuluma pit, zones of more intense brecciation alternate with folded zones, where brecciation is weak. Zones that display both $\mathrm{D}_{2}$ and $\mathrm{D}_{3}$ folds are brecciated, with some of the brecciation appearing more intense near fold hinge zones, i.e., in areas where the $S_{3}$, axial planar fracture cleavage was more intensely developed. Elsewhere (0418580-9688000; Figure 11c), strongly brecciated layers in sharp contact with non-brecciated meta-ironstone are folded during $\mathrm{D}_{3}$, indicating that some brecciation pre-dates $\mathrm{D}_{3}$ folding and is strata-bound, possibly even indicating a syn-sedimentary origin for this breccia. The breccia zones are truncated by low angle reverse faults of $\mathrm{D}_{5}$ origin and affected by $\mathrm{D}_{5}$ recumbent folding. In areas where $\mathrm{D}_{5}$ thrusts cut through the highly folded and fractured meta-ironstone units, brecciation also appears to occur in spatial association with the $\mathrm{D}_{5}$ fault planes.

Zones of brecciation show a close spatial relationship with meta-ironstone units and dykes belonging to the KIC, with breccia occurring along the margins of intrusive diorite-monzonite bodies, or with dykes intruding into breccia zones. In one location (GR0418636-9687782; Figure 11e-h) a porphyritic diorite dyke intruded into the breccia and displays highly irregular boundaries, involving 
a planar trail of irregular, blob-like intrusive bodies up to $2 \mathrm{~m}$ in size, with indented boundaries and irregular protrusions and apophyses of dyke material. This relationship suggests that the dyke was emplaced at the time the wall rocks had lost coherency, as a result of brecciation; i.e., this dyke was emplaced at the same time as breccia formation. In the Matandani pit, a raft of crackle breccia is embedded within a diorite intrusion with an $S_{3}$ foliation.

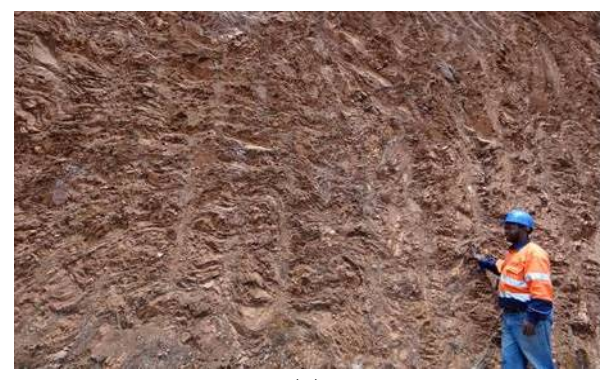

(a)

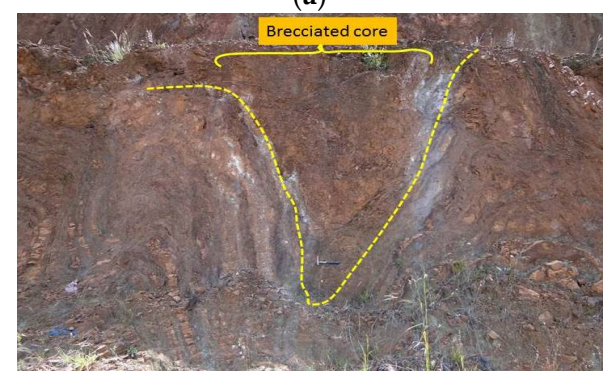

(c)

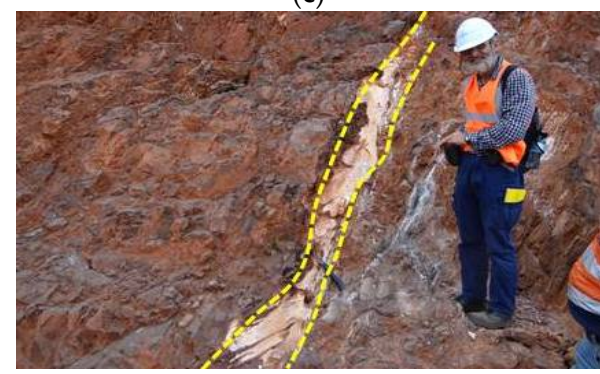

(e)

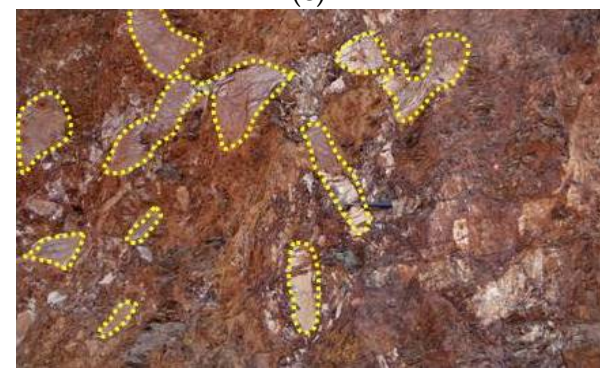

(g)

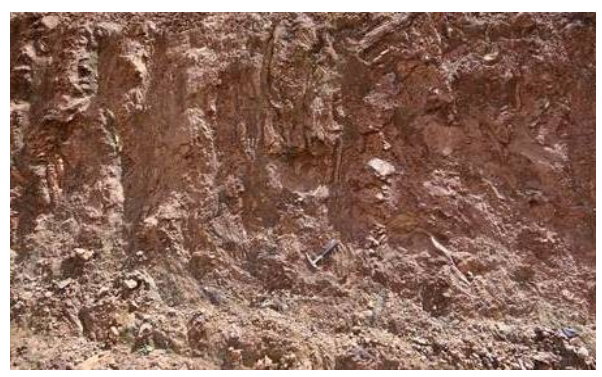

(b)

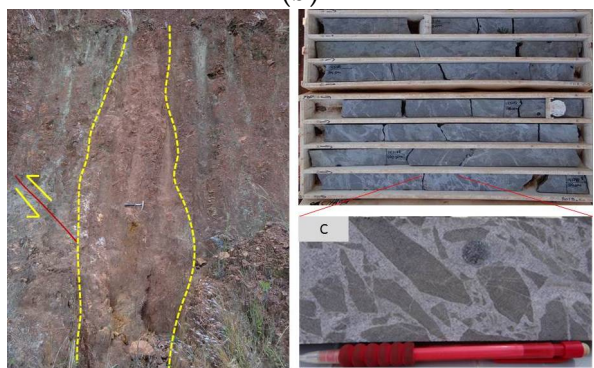

(d)

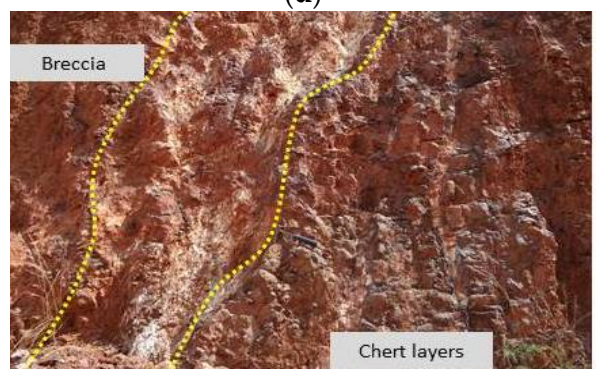

(f)

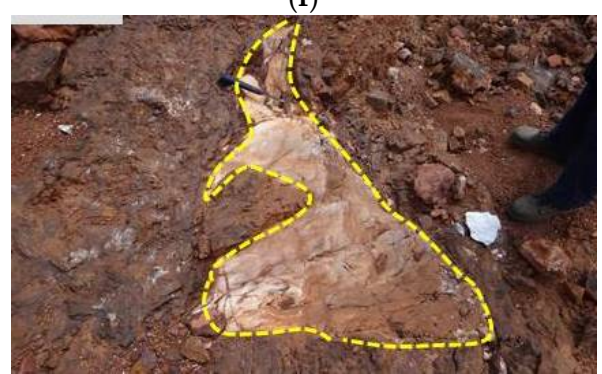

(h)

Figure 11. Examples of hydrothermal, syn- $\mathrm{D}_{3}$ breccia and intrusions in Kukuluma pit: (a,b) Progressive brecciation in meta-ironstones, including a complexly folded zone with crackle breccia, in which the original folded bedding is still visible (a), and more advanced brecciation, in which individual clasts have moved, but remnants of underlying folds are visible (b); (c) Layer-parallel breccia in the core of a $\mathrm{D}_{3}$ fold; (d) Fine-grained breccia pipe transecting a folded meta-ironstone package. The inset shows hydrothermal breccia in a diorite intrusive (drill hole ID: MTRD0005-588m); (e,f) Diorite dyke (outlined with yellow stipple line) with highly irregular margins is emplaced into the breccia zone; (g,h) Irregular blebs and fragments of diorite (outlined with yellow stipple line) mixed within the breccia near the intrusive contacts of the dyke shown in $(\mathbf{e}, \mathbf{f})$. 
Locally (e.g., GR0418621-9687801), polymict breccia occurs with rare mafic clasts mixed with meta-ironstone clasts, in chaotic breccia zones that transect folded meta-ironstone beds, indicating considerable movement between breccia clasts. Locally, the breccia bodies show a much higher degree of matrix material and a much smaller clast size along highly-altered, clay-rich planar zones that are reminiscent of fluid pathways in intrusive breccia pipes (Figure 11d).

Based on available evidence, most breccia in the Kukuluma and Matandani pits formed immediately preceding or during $\mathrm{D}_{3}$, during the emplacement of the diorite and monzonite bodies to which they are spatially linked. They are best developed in the chert-rich meta-ironstone unit affected by $\mathrm{D}_{2}-\mathrm{D}_{3}$ folding. Although most brecciation appears to have been in situ, as a result of magmatic-hydrothermal activity, some "streaming" of breccia blocks with pipe-like characteristics did occur.

Apart from the hydrothermal breccia associated with the KIC, there are planar breccia zones or cataclasite zones associated with $\mathrm{D}_{6}$ shear zones (Figure 5e), and syn-sedimentary chert clast breccias. The $\mathrm{D}_{6}$ breccia zones are limited in areal extent and restricted to places where $\mathrm{D}_{6}$ shear zones transect thick chert beds. Fragmental volcanoclastic sediments are common as intercalations within the meta-greywacke along the north wall of Kukuluma pit. These volcaniclastic rocks consist of strata-bound, matrix-supported breccia layers, with angular clasts and layer fragments of chert embedded in a matrix of arenitic sandstone. They differ from hydrothermal breccia in the proportion of clasts to matrix, the fact that some display grading, and that they are stratabound.

\section{Gold Mineralization}

The Kukuluma and Matandani deposits occur on a deeply weathered erosional plateau, interpreted to have formed part of the (Cretaceous) African Erosion Surface. Complete oxidation and weathering of all rock types occurs to depths of $>100 \mathrm{~m}$, and influenced gold distribution, with leaching of gold in the top $20 \mathrm{~m}$ of the regolith profile, and supergene enrichment of gold near the base of the regolith [47]. The gold anomalies in Area 3 occur along the edge of the plateau, where the thick regolith has been largely removed by erosion.

Initial trenching of a weak soil anomaly in deeply weathered and leached rock in the Kukuluma-Matandani area gave few indications of the large ore bodies at depth, although free "leaf" gold in old artisanal workings indicated gold was present. Exploratory drilling revealed a general 2-3 g/t increase in mean grade between 60 and $105 \mathrm{~m}$ deep at Kukuluma, and a planar zone of gold enrichment between the base of the regolith and the top of fresh rock [47]. Mining of the oxidized ore zones took place between 2002 and 2007, but once primary mineralization was reached mining stopped due to the refractory nature of the ore (arsenopyrite-rich with abundant graphite).

Gold mineralization is spatially related to (a) competent lithologies, including meta-ironstone and chert that are distributed in a complex manner due to $\mathrm{D}_{2}-\mathrm{D}_{4}$ fold interference; (b) the locally brecciated, intrusive contacts between the ironstone, diorite, and monzonite of the KIC; and (c) fracture networks of $\mathrm{D}_{6}$ and $\mathrm{D}_{7}$ origin (e.g., Figure 12; [26]). The ore zones that consist mostly of disseminated mineralization are generally tabular in shape, with a north-northwest strike and steep dips, parallel to the contact zones of intrusions (Figure 12). In the Kukuluma pit, it was observed that mineralization widens along the Juma shear, where it cuts across the nose of an east-plunging $D_{3}$ fold, and narrows again where the Juma shear runs oblique along the limbs of $\mathrm{D}_{3}$ folds. A second ore zone in the pit occurs along the Kasata shear, and is up to $50 \mathrm{~m}$ wide, trending $290^{\circ}$, where the Kasata shear intersects a complex $D_{2}-D_{3}$ antiformal fold interference structure in meta-ironstone; i.e., the presence of the $D_{3}$ fold hinge zones appears to have affected the width of ore zones. 


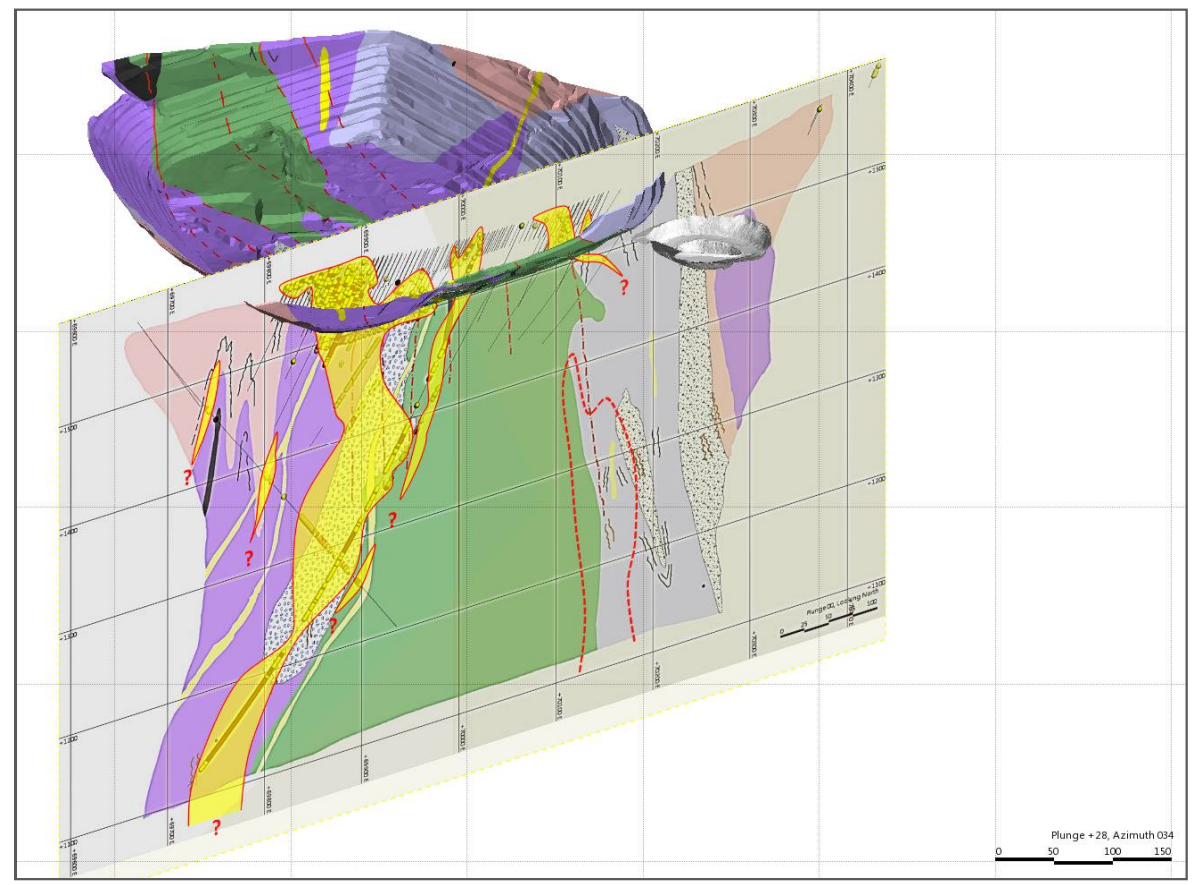

Figure 12. Example of a cross-section through Matandani pit, showing the ore distribution along the margin of a dioritic body (green) in contact with meta-ironstone (purple) and breccia (stipple). Other units include interbedded meta-ironstone, greywacke (light blue), and volcaniclastics (pink). The inferred position of $\mathrm{D}_{6}$ shear zones is shown with red stipple lines. The cut-off grade of the ore envelope shown in yellow is $0.5 \mathrm{ppm}$. The section is vertical and trends $060 / 240$, right-left.

Direct observations of ore zones targeted by artisanal workers in the Matandani and Kukuluma pits, as well as Area 3, indicate that high grade ore zones occur along $D_{7}$ fracture planes, which locally parallel and reactivate portions of the Juma and Kasata shears. This relationship is clearly visible in the western part of Matandani pit, where the main ore zone widens in a pocket of $D_{2}-D_{3}$ folded ironstone, transected by two strands of the $\mathrm{D}_{6}$ Kasata shear and overprinted by an east-southeast-trending $D_{7}$ fracture zone. Sulphide mineralization in the outcrop is spatially related to $D_{7}$ fracture planes, and occurs in association with grey to tan quartz stringers and sericite alteration. $\mathrm{D}_{7}$ faulting and associated gold mineralization and alteration in Matandani pit postdates the emplacement of a granite dyke at $2651 \pm 14 \mathrm{Ma}$ [28], which itself transects the $\mathrm{D}_{6}$ shear zones.

Higher grade ore in the Matandani, Kukuluma, and Area 3 deposits is normally found within meta-ironstone and chert units, with low-grade ore distributed over a larger range of lithologies (Table 2, Figure 12). For 30 diamond drill holes, representing a total length of $6094 \mathrm{~m}$ from Matandani (2160 m), Kukuluma (1787 m), and Area 3 (2147 m), which transect the main ore zones, the total length of mineralized rock at grades of $>0.1,>0.5,>1$, and $>5 \mathrm{ppm}$ gold was measured as a function of rock type. It was noted that rocks were not always logged in the same manner, so generalizations had to be made. All deposits show similar relationships between host lithology and ore grade, with $>75 \%$ of high-grade material ( $>5 \mathrm{ppm}$ ) hosted in grunerite-magnetite-chlorite-biotite-rich meta-ironstone and chert units (81\% at Matandani, $73 \%$ at Kukuluma, and $82 \%$ at Area 3; Table 2), suggesting a close relationship between mechanically competent, iron-rich lithologies and gold mineralization. Significant high-grade mineralization also occurs in sedimentary units ( $30 \%$ at Kukuluma) and in the monzodiorite-diorite intrusions (11\% at Matandani, $21 \%$ at Kukuluma, and 5\% at Area 3; Table 2). The latter are generally mineralized to within $\sim 3 \mathrm{~m}$ from the contact with mineralized meta-ironstone, especially near zones where the margin is sheared and meta-ironstone xenoliths occur within the intrusions. At lower grades ( $<1 \mathrm{ppm})$, other lithologies host some mineralization, but the bulk of 
the ore $(\sim 70-80 \%)$ continues to be hosted in the highly fractured, silicified meta-ironstone and chert lithologies (Table 2).

Gold in fresh meta-ironstone is fine-grained $(<20 \mu \mathrm{m})$, and occurs preferentially as inclusions in magnetite, pyrrhotite, pyrite, and arsenopyrite grains, which are spatially associated with fibrous grunerite aggregates, silicification, and chlorite-biotite alteration. Grunerite is not restricted to ore zones, but is also a regional metamorphic mineral that formed during $\mathrm{D}_{2}-\mathrm{D}_{3}$ events. In mineralized zones, magnetite is replaced by pyrrhotite, and arsenopyrite-pyrrhotite-pyrite-stibnite-scheelite assemblages occur in fracture networks, and as disseminations associated with gold. The alteration assemblage affects intrusive units of the KIC at or near the sheared contact zones (Figure 12). Higher grades are recorded in areas where arsenopyrite is dominant, and chlorite alteration less prominent. In highly mineralized zones, gold is associated with a network of mm-scale micro-fractures, probably of $\mathrm{D}_{7}$ origin, that are in-filled with pyrrhotite and arsenopyrite, and that are best developed in chert-rich layers of brecciated and folded meta-ironstone units. High-grade gold mineralization has also been observed in breccia zones that are not obviously $\left(D_{6}\right)$ sheared, but that are close to shears and occur next to the contact with the diorite and monzonite intrusives. In such areas, intense micro-fracturing can be observed in a drill core, with progressive infill of pyrrhotite in fractures within the ore zone.

Table 2. (a) Length of logged drill core expressed in metres, listed by grade and rock type for the Matandani, Kukuluma, and Area 3 west deposits. (b) Length of logged drill core expressed in \% of total, listed by grade and rock type for the Matandani, Kukuluma, and Area 3 west deposits. The lithological units listed comprise chert, including massively banded chert and highly silicified laminated sedimentary units; ironstone, referring to well-bedded, silicified, magnetite-rich units including BIF (banded ironstone formations), transitional with chert; Volc, which references volcanoclastic units including agglomerate, fragmental tuff, and ignimbrite; Seds represents sediments comprising alternating siltstone-shale units, with layers of coarser-grained sandstone, grit, and rare conglomerate; Bshale, or graphitic black shale; and Diorite, representing monzonite and diorite of the Kukuluma Intrusive Complex.

\begin{tabular}{|c|c|c|c|c|c|c|c|c|c|}
\hline \multicolumn{10}{|c|}{ (a) } \\
\hline Deposit & grade & Chert & Ironstone & Volc & Seds & Bshale & Diorite & FP & Total \\
\hline \multirow[t]{4}{*}{ Matandani } & $>0.1$ ppm Au (m) & 533.44 & 300.49 & 112.01 & 69.35 & 30.24 & 31.49 & 5.19 & 1082.21 \\
\hline & $>0.5$ ppm Au (m) & 287.65 & 208.38 & 32.76 & 29.04 & 5.45 & 15.60 & 2.54 & 581.42 \\
\hline & $>1.0$ ppm Au (m) & 193.59 & 174.70 & 20.04 & 18.64 & 1.50 & 15.60 & 0.00 & 424.07 \\
\hline & $>5.0$ ppm Au (m) & 33.28 & 65.17 & 9.00 & 1.00 & 0.00 & 13.00 & 0.00 & 121.45 \\
\hline \multirow[t]{4}{*}{ Kukuluma } & $>0.1$ ppm Au (m) & 175.79 & 283.07 & 73.07 & 92.11 & 17.97 & 40.47 & 0.00 & 682.48 \\
\hline & $>0.5$ ppm Au (m) & 111.30 & 111.41 & 16.20 & 52.89 & 4.00 & 8.30 & 0.00 & 304.10 \\
\hline & $>1.0$ ppm Au (m) & 86.65 & 45.98 & 3.00 & 41.75 & 3.00 & 4.30 & 0.00 & 184.68 \\
\hline & $>5.0$ ppm Au (m) & 21.00 & 4.45 & 1.00 & 15.98 & 0.00 & 11.00 & 0.00 & 53.43 \\
\hline \multirow[t]{4}{*}{ Area 3 West } & $>0.1$ ppm Au (m) & 127.75 & 265.34 & 49.86 & 7.00 & 17.35 & 17.00 & 0.00 & 484.30 \\
\hline & $>0.5$ ppm Au (m) & 60.11 & 128.50 & 27.00 & 1.00 & 2.50 & 10.00 & 0.00 & 229.11 \\
\hline & $>1.0$ ppm Au (m) & 37.36 & 93.34 & 12.70 & 0.00 & 0.00 & 4.00 & 0.00 & 147.40 \\
\hline & $>5.0$ ppm Au (m) & 10.21 & 28.44 & 2.00 & 0.00 & 0.00 & 2.00 & 0.00 & 42.65 \\
\hline \multicolumn{10}{|c|}{ (b) } \\
\hline Deposit & grade & Chert & Ironstone & Volc & Seds & Bshale & Diorite & FP & Total \\
\hline \multirow[t]{4}{*}{ Matandani } & $>0.1$ ppm Au (\%) & 49.29 & 27.77 & 10.35 & 6.41 & 2.79 & 2.91 & 0.48 & 100.00 \\
\hline & $>0.5$ ppm Au (\%) & 49.47 & 35.84 & 5.63 & 4.99 & 0.94 & 2.68 & 0.44 & 100.00 \\
\hline & $>1.0$ ppm Au (\%) & 45.65 & 41.20 & 4.73 & 4.40 & 0.35 & 3.68 & 0.00 & 100.00 \\
\hline & $>5.0$ ppm Au (\%) & 27.40 & 53.66 & 7.41 & 0.82 & 0.00 & 10.70 & 0.00 & 100.00 \\
\hline \multirow[t]{4}{*}{ Kukuluma } & $>0.1$ ppm Au (\%) & 25.76 & 41.48 & 10.71 & 13.50 & 2.63 & 5.93 & 0.00 & 100.00 \\
\hline & $>0.5$ ppm Au (\%) & 36.60 & 36.64 & 5.33 & 17.39 & 1.32 & 2.73 & 0.00 & 100.00 \\
\hline & $>1.0$ ppm Au (\%) & 46.92 & 24.90 & 1.62 & 22.61 & 1.62 & 2.33 & 0.00 & 100.00 \\
\hline & $>5.0 \mathrm{ppm} \mathrm{Au} \mathrm{( \% )}$ & 39.30 & 8.33 & 1.87 & 29.91 & 0.00 & 20.59 & 0.00 & 100.00 \\
\hline \multirow[t]{4}{*}{ Area 3 West } & $>0.1$ ppm Au (\%) & 26.38 & 54.79 & 10.30 & 1.45 & 3.58 & 3.51 & 0.00 & 100.00 \\
\hline & $>0.5$ ppm Au (\%) & 26.24 & 56.09 & 11.78 & 0.44 & 1.09 & 4.36 & 0.00 & 100.00 \\
\hline & $>1.0$ ppm Au (\%) & 25.35 & 63.32 & 8.62 & 0.00 & 0.00 & 2.71 & 0.00 & 100.00 \\
\hline & $>5.0 \mathrm{ppm} \mathrm{Au}(\%)$ & 23.94 & 66.68 & 4.69 & 0.00 & 0.00 & 4.69 & 0.00 & 100.00 \\
\hline
\end{tabular}




\section{Discussion}

\subsection{Tectonic and Magmatic History of the Central Kukuluma Terrain}

A summary of the deformation, intrusive, and mineralizing events encountered in the central part of the Kukuluma terrain is presented in Table 1. The deformation events in the Kukuluma-Matandani area comprise three groups of structures that formed during three separate stages in the tectonic history of the belt. These groups are (a) $\mathrm{D}_{1}$ structures that formed during Stage 1 , extensional deformation, which involved small-scale, syn-sedimentary growth faulting, layer-parallel shearing with silicification, and stratigraphic attenuation, and which formed at the time of sedimentation and early volcanism around $2717 \pm 12 \mathrm{Ma}$, in an oceanic plateau environment [28]; (b) penetrative structures $\left(\mathrm{D}_{2}-\mathrm{D}_{6}\right)$ that involved overprinting folding, shearing, and brecciation events during the main compressional Stage 2 of deformation, including an early episode of upright folding $\left(\mathrm{D}_{2}\right)$ followed by distributed shearing and cylindrical upright folding with northwest-trending axial planar surfaces $\left(\mathrm{D}_{3}\right)$, overprinted by open vertical folding $\left(\mathrm{D}_{4}\right)$ and then recumbent folding and thrusting $\left(\mathrm{D}_{5}\right)$ in response to north-south shortening. This was followed by the development of a network of brittle-ductile shear zones, recording reverse movements consistent with continued north-south shortening ( $\mathrm{D}_{6}$; Figure 9$)$, all happening before the emplacement of a set of felsic dykes around $2665 \mathrm{Ma}$ as a result of the Geita greenstone terrain docking against an older cratonic terrain to the south [28,39]; and (c) localized $\mathrm{D}_{7}$ structures that formed during Stage 3 extensional deformation (Figure 10), when strain was partitioned into discrete normal faults and joints $\left(\mathrm{D}_{7}\right)$ sometime after $2650 \mathrm{Ma}$ [28], during the stabilization phase of the craton [30].

Deformation events were accompanied by the emplacement of a diorite-monzonite suite that largely intruded during $\mathrm{D}_{3}$, and a granodiorite suite (mostly dykes) that intruded around 2665 Ma [28], probably after $\mathrm{D}_{6}$. Collectively, these intrusions form the Kukuluma Intrusive Complex (KIC, [26]). Rocks of the KIC have an adakite-like signature, but the trace element geochemistry and very narrow variation in Th/U ratios is inconsistent with a subduction origin [26]. It has, therefore, been proposed that the KIC formed by partial melting of garnet-bearing, mafic crust at the base of a thickened oceanic plateau, and did not involve subduction [26], similar to other volcanic units in the area [37] and mafic-felsic crust in other greenstone belts [20,51-54].

The intrusions of the KIC are spatially associated with breccia bodies that formed along intrusive margins with meta-ironstone units. Late-tectonic felsic porphyry dykes cross-cut all units and $\mathrm{D}_{1}-\mathrm{D}_{6}$ structures, and one such dyke, which is cut by D7 faults, has been mineralized and dated at $2651 \pm 14 \mathrm{Ma}$ [28]. This dyke provides an upper age constraint for gold mineralization in the area. With respect to gold mineralization, the ductile group of compressional $\mathrm{D}_{2-6}$ structures created the architecture that influenced the distribution of rock types favorable for gold precipitation, whereas the $D_{7}$ faults appear to have controlled fluid infiltration, which would have been facilitated by the extensional environment in which these structures formed $[8,12,18]$.

The deformation and intrusive sequence of events described for the gold deposits in the Kukuluma terrain (Table 1) is near-identical to the deformation-intrusive sequences described in the Nyankanga [25] and Geita Hill [24] deposits in the Central terrain, even though the latter occur across a major shear zone at somewhat lower peak metamorphic conditions (Figure 2). Both areas record early $D_{1}$ events associated with syn-sedimentary extensional faulting and chert formation along discordant zones. $\mathrm{D}_{2-4}$ events in both areas are near identical, with the exception that $\mathrm{D}_{2-4}$ structures in the Kukuluma terrain preserve a greater diversity in fold-axes orientation. Unlike the Nyankanga-Geita Hill area, the central parts of the Kukuluma terrain also preserve localized, planar $D_{3}$ high strain zones with northwest-plunging lineations, in which $S_{0}, S_{1}, S_{2}$, and $S_{3}$ fabrics have been transposed.

$\mathrm{D}_{5}$ events in the Kukuluma pit area are more clearly developed than at Geita Hill or Nyankanga [24,25], with recumbent folding showing a clear relationship with low-angle reverse 
faults. Such structures are common in greenstone belts, and may have resulted from the rise of diapirs and the consequent steepening of the margins of the greenstone belt $[55,56]$.

$\mathrm{D}_{6}$ brittle-ductile shears in the Kukuluma terrain correlate to the north-dipping sinistral thrust zones in Nyankanga and Geita Hill; they are identical in metamorphic grade and only vary in the orientation and dominant shear sense, but both are consistent with north-south shortening [24]. In the Kukuluma and Matandani pits, the network of $\mathrm{D}_{6}$ shear zones share a common, steeply west-northwest-plunging (Figure 10) intersection lineation that more or less parallels the $\mathrm{D}_{4}$ fold axes, a dominant cluster of $\mathrm{D}_{3}$ fold axes (Figure $6 \mathrm{~d}$ ), and the mineral elongation lineation in $\mathrm{D}_{3}$ high strain zones. This co-linearity of deformation features was also noted in the Geita Hill deposit [24], where mineralization followed the same general trend, and it has been interpreted to reflect a co-genetic relationship of $\mathrm{D}_{2}-\mathrm{D}_{6}$ events linked to the same large-scale compressional processes [24,25,57].

Later reactivation of $\mathrm{D}_{6}$ shears in Geita Hill and Nyankanga involved several events, including strike-slip and normal movements grouped as $\mathrm{D}_{7-8}$ events, whilst in the central Kukuluma terrain these events are grouped as $D_{7}$, with normal movement being dominant. In both areas, the late extensional events are spatially and temporally associated with gold mineralization that occurred after $2650 \mathrm{Ma}[24,35]$. In parallel with the deformation sequence, the intrusive rocks of the KIC correlate in composition and relative timing with the Nyankanga Intrusive Complex $[26,28,30]$, and both areas show evidence of igneous events associated with felsic dykes and lamprophyres that were emplaced after $\mathrm{D}_{6}$ and before $\mathrm{D}_{7}$.

The similarity in the deformation-intrusive histories of the Central and Kukuluma terrains suggests that the tectonic history for much of the GGB is similar, and that terrain boundaries internal to the GGB do not separate diverse domains, as has been suggested in accretionary terranes $[15,27,58]$. It also means that age constraints obtained from the Nyankanga-Geita area can probably be applied to the Kukuluma-Matandani area, and vice versa. Thus, $\mathrm{D}_{1-6}$ events near Kukuluma probably occurred at the same time as $\mathrm{D}_{1-6}$ events at Geita Hill [25,39], i.e., between 2720 and 2660 Ma, including the emplacement of the KIC, which, in comparison with the Nyankanga Intrusive Complex, may have occurred between 2700-2685 Ma [24,35]. A date of $2717 \pm 12 \mathrm{Ma}$ for syn-sedimentary volcanics from the Kukuluma pit [28] provides an estimate for the timing of extensional $\mathrm{D}_{1}$ events. Compressional $\mathrm{D}_{2-4}$ events at the Nyankanga and Geita pits are constrained to 2700-2675 Ma [25,35], whilst $\mathrm{D}_{5-6}$ events represent a later retrograde compressional stage of deformation, possibly at 2675-2660 Ma, as suggested by the ages obtained for the granodiorite dykes of the $\mathrm{KIC}[26,28]$. A late granodiorite dyke in Matandani pit constrains the timing of $\mathrm{D}_{7}$ normal faulting and mineralization to $<2650 \mathrm{Ma}$, consistent with observations in Geita Hill, where mineralization is <2644 Ma [24,35], which also coincided with the emplacement of 2620-2660 Ma granitoids to the east, north, and west of the GGB [30].

\subsection{Controls on Gold Mineralization}

Spatially, gold mineralization within the Kukuluma and Matandani deposits is associated with $D_{6,7}$ shear zones, located along the contact zone between the diorite intrusions of the KIC and magnetite-rich, meta-ironstone units within the surrounding volcano sedimentary package (e.g., Figure 12). High-grade mineralization is also closely associated with networks of extensional $D_{7}$ fractures, where they occur in ironstone and metasediment away from $\mathrm{D}_{6}$ shear zones. Ore zones occur almost entirely within the meta-ironstone units, and differ in this respect from the mineralization in Nyankanga and Geita Hill, where diorite of the Nyankanga Intrusive Complex is widely mineralized, be it at a lower grade $[23,25,41]$. The ore zones widen where $D_{6,7}$ shear zones traverse intensely folded and highly brecciated areas. $\mathrm{D}_{3}$ fold axial zones and syn- $\mathrm{D}_{3}$ hydrothermal breccia zones near KIC intrusive margins were especially conducive to the infiltration of mineralizing fluids, which infiltrated the rock along preexisting micro-fracture networks. However, this relationship only holds where mineralized $\mathrm{D}_{6}$ shear zones are in close proximity to the folded and brecciated areas-i.e., brecciation of meta-ironstone units in itself does not guarantee gold mineralization. 
These relationships indicate that the $D_{7}$ fracture zones in the Matandani-Kukuluma area acted as upper-crustal channels for the mineralizing fluids, facilitating the infiltration into fractured zones offered by the strongly folded and brecciated meta-ironstones [59]. In this context, it is important to note that the distribution of the meta-ironstone units is highly complex as a result of $\mathrm{D}_{2-4}$ fold interference, and therefore, the intersection zones of the $D_{2-4}$ folded ironstones, $D_{6,7}$ shears, and fracture zones is highly discontinuous, which contributes to the complex distribution patterns of the ore zones in the area.

Earlier mine reports argued that mineralization was controlled by the Juma and Kasata shears (Figure 3), and that their apparent displacement between the Kukuluma and Matandani pits was the result of later east-west sinistral faults. A similar east-west fault was assumed to have displaced the southern end of the Juma shear, in order to account for mineralization in Area 3 to the east $[48,60]$. Pit exposure shows that the Juma and Kasata shears anastomose and change in orientation from west-trending to northwest-trending, with no evidence for offsets by later east-west faults. Likewise, the eastern tip of the Juma fault displays a complex fault splay, characteristic for fault tips or terminations [46], with no evidence of displacement by cross-cutting faults. The Juma and Kasata shears do, however, show evidence for an earlier $\mathrm{D}_{6}$ compressional stage, overprinted by a later $\mathrm{D}_{7}$ extensional stage; the late east-west fracture zones identified [48] represent the cross-cutting $\mathrm{D}_{7}$ structures reported here, which are associated with hydrothermal alteration but have no major displacements. Thus, the spaced distribution of mineralization from Area 3 via Kukuluma to Matandani should be understood in terms of an en echelon array along a west-northwest-trending corridor, rather than a continuous northwest-trending ore zone displaced by later east-west faults. This en echelon array of faults did not accommodate large displacements, neither during $\mathrm{D}_{6}$ nor $\mathrm{D}_{7}$, because the strike length of the faults is generally $<500 \mathrm{~m}[61,62]$. The en echelon array probably originally formed in compression during $D_{6}$, and was reactivated and partly overprinted by normal faults during $D_{7}$, which developed along east-west corridors [24,48], and possibly visible as east-trending lineaments in geophysical data sets. Even though displacements would have been small, fluid ascents and penetration could have been highly effective during $D_{7}$ extension, as a small shift in the far-field stress could have greatly enhanced the permeability of preexisting micro-fracture networks and facilitated improved fluid-rock interactions $[12,59,63-66]$. In this context, it is important to note that the ore zones in the Kukuluma and Matandani pits widen where the $D_{6,7}$ shear zones display S-like bends (from northwest to west to northwest-trending). Such S-bends would be constraining [46] during $\mathrm{D}_{6}$ reverse faulting, but would be areas of maximum dilatancy during $D_{7}[9,12,63]$. The drop in fluid pressure and possibly temperature that would have occurred along the micro-fracture zones in extension would also have played a role in ore deposition [12].

The close spatial relationship of gold with meta-ironstone and the intrusive margins of the KIC indicate a litho-chemical control on mineralization, with sulphidation of the magnetite-rich units being particularly important. It is therefore assumed that much of the gold entered the system as sulphur complexes, which destabilized upon contact with Fe-rich lithologies, i.e., magnetite-rich units [25,67-71]. Compared to other major deposits in the GGB, mineralization in Kukuluma and Matandani is more pyrrhotite-arsenopyrite-rich, which may reflect a combination of higher metamorphic grade, reduced conditions due to the presence of graphitic shale, and host-rock control. The presence of porphyry dykes in association with mineralization, not just in the Matandani pit but also at Geita Hill [24] and Nyankanga [25], would suggest that igneous fluids may have caused mineralization; even though for Archaean Greenstone terrains in general devolatization reactions during regional metamorphism are generally credited as being the primary source for mineralizing fluids $[3,8,70]$. It is beyond the scope of this paper to fully discuss the origin of gold-bearing fluids, which will require additional isotopic and fluid inclusion studies.

In terms of the timing of gold mineralization in the Kukuluma terrain, the situation is similar to the Geita Hill and Nyankanga deposits, with mineralization spatially linked to $\mathrm{D}_{2}-\mathrm{D}_{3}$ fold noses and $\mathrm{D}_{6}$ reverse faults that formed during the compressional stages of the deformation history [25]. 
The mineralizing event (i.e., $\mathrm{D}_{8}$ at Nyankanga and Geita Hill $[24,25]$ and $\mathrm{D}_{7}$ at Matandani-Kukuluma; Table 1), however, is late-tectonic, and associated with normal fault reactivation of the older reverse faults. The mineralizing events post-date an intrusive event, dated at $2651 \mathrm{Ma}$ in the Matandani pit [28] and at $2644 \mathrm{Ma}$ in the Geita Hill deposit [35], where lamphrophyre dykes occured in association with mineralization [24,35]. Thus, whilst the ore-body geometries are entirely controlled by deformational geometries and lithological distributions that formed during the second stage (i.e., $\sim 2700-2665 \mathrm{Ma}$ ) evolution of the GGB, the actual mineralizing events probably occurred later, when fluids, possibly linked to a deeper igneous source, moved into the dilatant zones during extension [9,24,25]. A similar relative timing relationship of deformation structures, intrusions, and gold mineralization also exists in other parts of the Tanzania Craton ([72-74]; for example, in the Golden Pride deposit in the Nzega Greenstone Belt (Figure 1), mineralization was introduced along a crustal scale shear zone during late-stage reactivation, and accompanied by the intrusion of lamprophyre and quartz porphyry dykes. Mineralization was concentrated along late cross-cutting fractures near redox fronts provided by BIFs [74].

The structural controls on gold mineralization at Kukuluma and Matandani conform with models for Archaean gold mineralization more broadly, as summarized by [8,9], in the sense that mineralization is late-tectonic, appears to occur as a single event during a shift in the far field stress, precedes cratonic stabilization, and is associated with a range of structural traps created earlier in the deformation and intrusive history of the belt. However, the Kukuluma, Matandani, and Area 3 deposits do not fit the orogenic model, as defined by [9,70] or [2]. In review papers on gold mineralization, the Geita mine is commonly classified as a Neoarchaean, BIF-hosted, orogenic gold deposit [1-3,6,7] related to subduction-accretion systems, with all mafic sequences deposited in a subduction-back arc environment $[27,36]$. More recent work [24,25,37,39] shows that this interpretation needs adjustment. Rather than forming in a classic orogenic setting, mineralization entered the greenstone belt during an extensional phase concomitant with the emplacement of widespread high-K granites [30], 20-30 Ma after compressional deformation and accretion of the greenstone sequence. The mafic-intermediate volcanics in the GGB evolved from melt segregation of a primitive mantle, to form thick oceanic plateaus away from subduction systems and accretionary margins [37,39]. Compressional deformation events coincided with the emplacement of diorite-monzonite complexes like the KIC, which formed from partial melting of the garnet-bearing mafic crust at the base of the oceanic plateaus, suggesting that the greenstone sequence may have never experienced the accretion-subduction processes as postulated by earlier workers [27]. If so, this would invalidate a traditional orogenic setting for the gold deposits in the GGB [1].

\section{Conclusions}

Detailed mapping of the central part of the Kukuluma terrain in the eastern GGB shows that the deformation-intrusive history of the area (Table 1) is near identical to the geological history of the Central terrain, which hosts the world-class Nyankanga and Geita Hill deposits. This similarity occurs across major shear zones, and suggests that the geological history of much of the GGB is similar, with syn-sedimentary extension $\left(D_{1}\right)$ followed by an early compressional-accretionary stage $\left(D_{2-6}\right)$ between 2700-2665 Ma, associated with the emplacement of internal intrusions of the KIC, a later extensional stage $\left(D_{7}\right)$ associated with a second generation of felsic intrusions, and gold mineralization that occurred after $2650 \mathrm{Ma}$.

The geometry of the ore bodies at Kukuluma and Matandani is controlled by the distribution of magnetite-rich meta-ironstone, near the margins of monzonite-diorite bodies of the KIC where they are cut by $\mathrm{D}_{7}$ fractures. The lithological contacts act as redox boundaries, with high-grade mineralization enhanced in zones of improved permeability and fluid infiltration, including syn- $\mathrm{D}_{3}$ hydrothermal breccia zones, $D_{2}-D_{3}$ fold hinge domains associated with a high density of micro-fracturing, and $D_{6}$ shears with associated damage zones. The actual mineralizing events were late-tectonic $(<2650 \mathrm{Ma})$, 
and occurred in an extensional setting during $\mathrm{D}_{7}$. Extension facilitated the infiltration of mineralizing fluids along preexisting micro-fracture networks of $\mathrm{D}_{2}-\mathrm{D}_{6}$ origin, as well as $\mathrm{D}_{7}$ deformation zones.

The Kukuluma and Matandani deposits provide excellent examples of complex trapping structures that formed as a result of multiple overprinting deformation events before the gold was introduced [9]. Thus, whilst gold mineralization is late-tectonic, ore body geometries are associated with older structures and lithological boundaries.

In the GGB, deformation and intrusive sequences on an outcrop scale are similar to other greenstone belts. However, the major gold deposits in the GGB lack the proximity of crustal-scale shear zones, are associated with intrusive complexes like the KIC, do not show a clear link to a subduction-accretion setting, and formed late-tectonically during an extensional phase. These deposits are not characteristic of typical orogenic gold deposits.

Acknowledgments: This study is part of a PhD study undertaken by the first author at James Cook University. SDK would like to thank James Cook University for waiving the tuition fees and Geita Gold Mine for providing the research funding for this study.

Author Contributions: S.D.K., P.H.G.M.D., I.V.S., T.B. and S.L.K. have conceived and designed the project and performed the field work; S.D.K. and P.H.G.M.D. analysed the data; S.D.K., P.H.G.M.D. and I.V.S. wrote the paper.

Conflicts of Interest: The authors declare no conflict of interest.

\section{Appendix Fault Kinematic Analysis}

Kinematic data from faults can be used to reconstruct paleo-stress fields [75]. To do this, information is required on the orientation of the fault plane, the slip direction visible as slickenlines, striations or gouge marks, and the sense of movement. Stress inversion techniques rely on the assumption that the slip direction coincides with the resolved shear stress on the fault plane, and that the set of faults used in the analysis formed or were active in response to the same far-field stress. Fault-slip data can be inverted to a reduced moment tensor, with information on the direction of the principal stress axes and their relative size expressed as a stress ratio [76,77]. This reduced stress tensor can be calculated using the $P$ (principal compression) and $T$ (principal tension) axes that bisect the fault plane, and an auxiliary plane perpendicular to the fault, by using least-square minimization techniques of direction cosines [49] or iterative methods that test a variety of possible tensor solutions [78]. Stress axes can also be determined graphically using the right dihedron method [76,79], which constrains the orientation of principal stress axes by determining the area of maximum overlap of compressional and extensional quadrants for a suite of faults.

In analyzing the fault-slip data, we have used a linked Bingham distribution tensor calculated with the program FaultKinWin [80], following methods described by $[49,81]$. The FaultKinWin programme [80] uses the distribution of the $P$ and $T$ axes for a suite of faults [75], in order to calculate a Bingham axial distribution based on a least-squares minimization technique for direction cosines. In this technique, the dihedral angle between the fault plane and an auxiliary plane is $90^{\circ}$ and bisected by the $P$ and $T$ axes. The eigenvectors for the calculated Bingham axial distribution provide average orientations for the maximum, minimum, and intermediate concentration direction of the $P$ and $T$ axes, and the eigenvalues provide a measure of the relative concentration or distribution of $P$ and $T$ axes. These eigenvalues vary between -0.5 and +0.5 , with maximum values reached when the $P$ and $T$ axes are perfectly concentrated. Variations in the eigenvalues (ev) can be linked to the stress regime, using the relative size of the normalized eigenvalues expressed in a ratio, Rev, with $\operatorname{Rev}=\left(\mathrm{ev}_{2}-\mathrm{ev}_{3}\right) /\left(\mathrm{ev}_{1}-\mathrm{ev}_{3}\right)$ (constrictional stress: $\operatorname{Rev}=1$ when $\mathrm{ev}_{1}=\mathrm{ev}_{2} ;$ plane stress: $\operatorname{Rev}=0.5$ when $\mathrm{ev}_{2}=0$; flattening stress: $\operatorname{Rev}=0 \mathrm{when}_{\mathrm{ev}}=\mathrm{ev}_{3}$ ). The FaultKinWin programme output is a plot of linked Bingham axes, with eigenvalues and a related fault plane solution diagram displaying $P$ and $T$ quadrants in a manner similar to earthquake focal mechanisms (Figures 9 and 10).

Although stress analysis from fault slip data is widely applied, debate continues whether the obtained solutions represent a stress field or provide a measure of strain and strain rate $[82,83]$. 
Marrett [49], along with Allmendinger and Faultkinwin [80], using FaultKinWin, prefer to interpret the fault plane solutions as an indicator of strain rather than stress.

Here, the linked Bigham fault plane solution through FaultKinWin has been interpreted as an indication of the paleo-stress field. In doing this, we are aware of the various pitfalls. Faults, once formed, can interact in complex ways in response to an imposed stress field due to scale-dependent strain partitioning, complex fault interactions, block rotations, inhomogeneities in the rock mass, etc. [83]. In spite of such limitations, the paleo-stress analysis technique has been successfully applied in a wide variety of tectonic settings $[18,66,84]$, and we believe it provides valuable insights to the tectonic controls on gold mineralization at Kukuluma and Matandani.

Misfits in collected datasets may have resulted from observational errors, the mixing of unrelated data points, or limitations in the approach used. They can also be due to non-uniform stress fields, as a result of fracture interactions, anisotropies in the rock mass, block rotations, or slip partitioning. In near vertical shear fractures there is the added problem that a small rotation of the fracture plane around a horizontal axis can change it, from a normal fracture compatible with the overall data set to a reverse fracture that is radically incompatible when using the computer programs. In calculating a Bingham tensor solution using FaultKinWin, all data points were included. It is stressed that throughout the analyses of datasets, very few data points were incompatible with the final results, suggesting generally homogeneous data

As a general rule, the results from the paleo-stress analyses are best constrained for large data sets that combine fracture planes with different directions and movement sense. Thus, conjugate fracture sets, or Riedel, anti-Riedel, and P-shear arrays, provide good results that are more likely to be indicative of the regional paleo-stress field, especially if the stress inversion is based on at least 15 fracture planes [76,84]; sites in which only few planes, or planes in a limited number of directions, can be measured to provide at best an indication only of the local paleo-stress field, which may or may not conform with the regional results.

\section{References}

1. Goldfarb, R.J.; Groves, D.I.; Gardoll, S. Orogenic gold and geologic time: A global synthesis. Ore Geol. Rev. 2001, 18, 1-75. [CrossRef]

2. Goldfarb, R.J.; Baker, T.; Dube, B.; Groves, D.; Hart, C.; Gosslein, P. Distribution, character and genesis of gold deposits in metamorphic terranes. In Economic Geology One Hundredth Anniversary Volume; Society of Economic Geologists, Inc.: Littleton, CO, USA, 2005; pp. 407-450.

3. Groves, D.I.; Vielreicher, R.M.; Goldfarb, R.J.; Condie, K.C. Controls on the heterogeneous distribution of mineral deposits through time. Geol. Soc. Lond. Spec. Publ. 2005, 248, 71-101. [CrossRef]

4. Laznicka, P. Giant metallic deposits-A century of progress. Ore Geol. Rev. 2014, 62, 259-314. [CrossRef]

5. Groves, D.I.; Goldfarb, R.J.; Gebre-Mariam, M.; Hagemann, S.G.; Robert, F. Orogenic gold deposits: A proposed classification in the context of their crustal distribution and relationship to other gold deposit types. Ore Geol. Rev. 1998, 13, 7-27. [CrossRef]

6. Bierlein, F.P.; Groves, D.I.; Cawood, P.A. Metallogeny of accretionary orogens-The connection between lithospheric processes and metal endowment. Ore Geol. Rev. 2009, 36, 282-292. [CrossRef]

7. Bierlein, F.P.; Groves, D.I.; Goldfarb, R.J.; Dubé, B. Lithospheric controls on the formation of provinces hosting giant orogenic gold deposits. Miner. Depos. 2006, 40, 874-886. [CrossRef]

8. Goldfarb, R.J.; Groves, D.I. Orogenic gold: Common or evolving fluid and metal sources through time. Lithos 2015, 233, 2-26. [CrossRef]

9. Groves, D.I.; Santosh, M.; Goldfarb, R.J.; Zhang, L. Structural geometry of orogenic gold deposits: Implications for exploration of world-class and giant deposits. Geosci. Front. 2018. [CrossRef]

10. Kabete, J.M.; Groves, D.I.; McNaughton, N.J.; Mruma, A.H. A new tectonic and temporal framework for the tanzanian shield: Implications for gold metallogeny and undiscovered endowment. Ore Geol. Rev. 2012, 48, 88-124. [CrossRef] 
11. Sanislav, I.V.; Kolling, S.L.; Brayshaw, M.; Cook, Y.A.; Dirks, P.H.G.M.; Blenkinsop, T.G.; Mturi, M.I.; Ruhega, R. The geology of the giant Nyankanga gold deposit, Geita Greenstone Belt, Tanzania. Ore Geol. Rev. 2015, 69, 1-16. [CrossRef]

12. Frimmel, H.E. Earth's continental crustal gold endowment. Earth Planet. Sci. Lett. 2008, 267, 45-55. [CrossRef]

13. Sibson, R.H. Controls on maximum fluid overpressure defining conditions for mesozonal mineralisation. J. Struct. Geol. 2004, 26, 1127-1136. [CrossRef]

14. Cox, S.F. Coupling between deformation, fluid pressures, and fluid flow in ore-producing hydrothermal systems at depth in the crust. In One Hundredth Anniversary Volume; Hedenquist, J.W., Thompson, J.F.H., Goldfarb, R.J., Richards, J.P., Eds.; Society of Economic Geologists: Littleton, CO, USA, 2005.

15. Robert, F.; Poulsen, K.H.; Cassidy, K.F.; Hodgson, C.J. Gold metallogeny of the Superior and Yilgarn Cratons. In One Hundredth Anniversary Volume; Hedenquist, J.W., Thompson, J.F.H., Goldfarb, R.J., Richards, J.P., Eds.; Society of Economic Geologists: Littleton, CO, USA, 2005.

16. Bateman, R.; Hagemann, S. Gold mineralisation throughout about 45 MA of Archaean orogenesis: Protracted flux of gold in the Golden Mile, Yilgarn Craton, Western Australia. Miner. Depos. 2004, 39, 536-559. [CrossRef]

17. Blewett, R.S.; Henson, P.A.; Roy, I.G.; Champion, D.C.; Cassidy, K.F. Scale-integrated architecture of a world-class gold mineral system: The Archaean Eastern Yilgarn Craton, Western Australia. Precambrian Res. 2010, 183, 230-250. [CrossRef]

18. Baker, T.; Bertelli, M.; Blenkinsop, T.; Cleverley, J.S.; McLellan, J.; Nugus, M.; Gillen, D. P-T-X conditions of fluids in the Sunrise Dam gold deposit, Western Australia, and implications for the interplay between deformation and fluids. Econ. Geol. 2010, 105, 873-894. [CrossRef]

19. Jones, S. Contrasting structural styles of gold deposits in the leonora domain: Evidence for early gold deposition, eastern goldfields, western australia. Aust. J. Earth Sci. 2014, 61, 881-917. [CrossRef]

20. Dirks, P.H.G.M.; Charlesworth, E.G.; Munyai, M.R.; Wormald, R. Stress analysis, post-orogenic extension and 3.01GA gold mineralisation in the Barberton Greenstone Belt, South Africa. Precambrian Res. 2013, 226, 157-184.

21. Bédard, J.H.; Brouillette, P.; Madore, L.; Berclaz, A. Archaean cratonization and deformation in the northern Superior Province, Canada: An evaluation of plate tectonic versus vertical tectonic models. Precambrian Res. 2003, 127, 61-87. [CrossRef]

22. Bédard, J.H. A catalytic delamination-driven model for coupled genesis of archaean crust and sub-continental lithospheric mantle. Geochimica et Cosmochimica Acta 2006, 70, 1188-1214. [CrossRef]

23. Hamilton, W.B. Plate tectonics began in neoproterozoic time, and plumes from deep mantle have never operated. Lithos 2011, 123, 1-20. [CrossRef]

24. Van Kranendonk, M.J. Cool greenstone drips and the role of partial convective overturn in Barberton greenstone belt evolution. J. Afr. Earth Sci. 2011, 60, 346-352. [CrossRef]

25. Borg, G. The geita gold deposit, NW-Tanzania. Geology, ore petrology, geochemistry and timing of events. Geol. Jahrb. D 1994, D100, 545-595.

26. Sanislav, I.V.; Brayshaw, M.; Kolling, S.L.; Dirks, P.H.G.M.; Cook, Y.A.; Blenkinsop, T.G. The structural history and mineralization controls of the world-class Geita Hill gold deposit, Geita Greenstone Belt, Tanzania. Miner. Depos. 2017, 52, 257-279. [CrossRef]

27. Kwelwa, S.D.; Sanislav, I.V.; Dirks, P.H.G.M.; Blenkinsop, T.; Kolling, S.L. The petrogenesis of the Neoarchean Kukuluma Intrusive Complex, NW Tanzania. Precambrian Res. 2018, 305, 64-78. [CrossRef]

28. Kwelwa, S.D.; Sanislav, I.V.; Dirks, P.H.G.M.; Blenkinsop, T.; Kolling, S.L. Zircon U-Pb ages and Hf isotope data from the Kukuluma Terrain of the Geita Greenstone Belt, Tanzania Craton: Implications for stratigraphy, crustal growth and timing of gold mineralization. J. Afr. Earth Sci. 2018, 139, 38-54. [CrossRef]

29. Sanislav, I.V.; Dirks, P.H.G.M.; Blenkinsop, T.; Kolling, S.L. The tectonic history of a crustal-scale shear zone in the tanzania craton from the Geita Greenstone Belt, NW-Tanzania Craton. Precambrian Res. 2018, 310, 1-16. [CrossRef]

30. Sanislav, I.V.; Wormald, R.J.; Dirks, P.H.G.M.; Blenkinsop, T.G.; Salamba, L.; Joseph, D. Zircon U-Pb ages and $\mathrm{Lu}-\mathrm{Hf}$ isotope systematics from late-tectonic granites, Geita Greenstone Belt: Implications for crustal growth of the Tanzania Craton. Precambrian Res. 2014, 242, 187-204. [CrossRef]

31. Gabert, G. Lithostratigraphic and tectonic setting of gold mineralization in the Archean Cratons of Tanzania and Uganda, East Africa. Precambrian Res. 1990, 46, 59-69. [CrossRef] 
32. Kuehn, S.; Ogola, J.; Sango, P. Regional setting and nature of gold mineralization in Tanzania and southwest Kenya. Precambrian Res. 1990, 46, 71-82. [CrossRef]

33. Borg, G. New aspects of the lithostratigraphy and evolution of the Siga Hills, an Archaean Granite-Greenstone Terrain in NW Tanzania. Zeitschrift fur Angewandte Geologie 1992, 38, 89-93.

34. Borg, G.; Shackleton, R.M. The Tanzania and Ne-Zaire Cratons; Oxford University Press: Oxford, UK, 1997.

35. Borg, G.; Krogh, T. Isotopic age data of single zircons from the Archaean Sukumaland Greenstone Belt, Tanzania. J. Afr. Earth Sci. 1999, 29, 301-312. [CrossRef]

36. Manya, S.; Maboko, M.A.H. Geochemistry of the neoarchaean mafic volcanic rocks of the geita area, NW Tanzania: Implications for stratigraphical relationships in the Sukumaland greenstone belt. J. Afr. Earth Sci. 2008, 52, 152-160. [CrossRef]

37. Cook, Y.A.; Sanislav, I.V.; Hammerli, J.; Blenkinsop, T.G.; Dirks, P.H.G.M. A primitive mantle source for the Neoarchean mafic rocks from the Tanzania Craton. Geosci. Front. 2016, 7, 911-926. [CrossRef]

38. Kabete, J.M.; McNaughton, N.J.; Groves, D.I.; Mruma, A.H. Reconnaissance shrimp U-Pb zircon geochronology of the Tanzania Craton: Evidence for Neoarchean granitoid-greenstone belts in the central Tanzania Region and the Southern East African Orogen. Precambrian Res. 2012, 216-219, 232-266. [CrossRef]

39. Sanislav, I.V.; Blenkinsop, T.G.; Dirks, P.H.G.M. Archean crustal growth through successive partial melting events in an oceanic plateau-like setting in the Tanzania Craton. Terra Nova 2018, 1-10. [CrossRef]

40. Manya, S. Petrogenesis and emplacement of the TTG and K-rich granites at the Buzwagi gold mine, northern Tanzania: Implications for the timing of gold mineralization. Lithos 2016, 256-257, 26-40. [CrossRef]

41. Borg, G.; Lyatuu, D.R.; Rammlmair, D. Genetic aspects of the Geita and Jubilee Reef Archean BIF-hosted gold deposits, Tanzania. Geologische Rundschau 1990, 79, 355-371. [CrossRef]

42. Skead, M.B.; Chuwa, G. Geita West Deposit_Geological and Mineralization Model; Internal AngloGold Report; Geita Gold Mine-Exploration Departmen: Geita, Tanzania, 2003; p. 26.

43. Painter, M. Mineralisation and Structural Architecture of the Geita Hill Shear Zone; Internal AngloGold Report; Geita Gold Mine: Geita, Tanzania, 2004; p. 26.

44. Hofmann, A.; Dirks, P.H.G.M.; Jelsma, H.A. Late Archaean foreland basin deposits, Belingwe greenstone belt, Zimbabwe. Sediment. Geol. 2001, 141-142, 131-168. [CrossRef]

45. Thiessen, R. Two-dimensional refold interference patterns. J. Struct. Geol. 1986, 8, 563-573. [CrossRef]

46. Fossen, H. Structural Geology; Cambridge University Press: Cambridge, UK, 2010.

47. Bansah, D.; Chase, R.; Davidson, A.; Michael, H.; Skead, M. The Geita and Kukuluma mineralized trends, Lake Victoria Goldfield, Tanzania-Ore body characteristics and project planning. In Proceedings of the 4th International Mining Geology Conference, Coolum, Queensland, Australia, 14-17 May 2000; pp. 115-127.

48. Skead, M.B. Geology and Structure of the Kukuluma Deposit, Geita Greenstone Belt, Tanzania; Internal AngloGold Report; Geita Gold Mine: Geita, Tanzania, 2003; p. 27.

49. Marrett, R.; Allmendinger, R.W. Kinematic analysis of fault-slip data. J. Struct. Geol. 1990, 12, $973-986$. [CrossRef]

50. Allmendinger, R.W.; Cardozo, N.; Fisher, D.M. Structural Geology Algorithms: Vectors and Tensors; Cambridge University Press: Cambridge, UK; New York, NY, USA, 2012.

51. Vlaar, N.J.; van Keken, P.E.; van den Berg, A.P. Cooling of the earth in the Archaean: Consequences of pressure-release melting in a hotter mantle. Earth Planet. Sci. Lett. 1994, 121, 1-18. [CrossRef]

52. Champion, D.C.; Smithies, R.H. Chapter 4.3 Geochemistry of Paleoarchean Granites of the East Pilbara Terrane, Pilbara Craton, Western Australia: Implications for Early Archean Crustal Growth. In Developments in Precambrian Geology; van Kranendonk, M.J., Smithies, R.H., Bennett, V.C., Eds.; Elsevier: New York, NY, USA, 2007; Volume 15, pp. 369-409.

53. Smithies, R.H.; Champion, D.C.; Van Kranendonk, M.J. Formation of paleoarchean continental crust through infracrustal melting of enriched basalt. Earth Planet. Sci. Lett. 2009, 281, 298-306. [CrossRef]

54. Van Kranendonk, M. Two types of Archean continental crust: Plume and plate tectonics on early Earth. Am. J. Sci. 2010, 310, 1187-1209. [CrossRef]

55. Jelsma, H.A.; Vinyu, M.L.; Wijbrans, J.R.; Verdurmen, E.A.T.; Valbracht, P.J.; Davies, G.R.; Valbracht, P.J. Constraints on Archaean crustal evolution of the Zimbabwe Craton: A U-Pb zircon, Sm- $\mathrm{Nd}$ and $\mathrm{Pb}-\mathrm{Pb}$ whole-rock isotope study. Contrib. Mineral. Petrol. 1996, 124, 55-70. [CrossRef]

56. Lin, S.; Beakhouse, G.P. Synchronous vertical and horizontal tectonism at late stages of Archean cratonization and genesis of Hemlo gold deposit, Superior Craton, Ontario, Canada. Geology 2013, 41, 359-362. [CrossRef] 
57. Sanislav, I.V. Porphyroblast rotation and strain localization: Debate settled!: Comment. Geology 2010, 38, e204. [CrossRef]

58. Dirks, P.H.G.M.; Jelsma, H.A.; Hofmann, A. Thrust-related accretion of an Archaean greenstone belt in the midlands of Zimbabwe. J. Struct. Geol. 2002, 24, 1707-1727. [CrossRef]

59. Cox, S.; Knackstedt, M.; Braun, J. Principles of structural control on permeability and fluid flow in hydrothermal systems. Rev. Econ. Geol. 2001, 14, 1-24.

60. Porter, C. Structural Analysis and Target Generation, Kukuluma-Matandani Area, Geita Greenstone Belt, Tanzania; Internal AngloGold Report; Geita Gold Mine: Geita, Tanzania, 2002; p. 24.

61. Schultz, R.A.; Fossen, H. Displacement-length scaling in three dimensions: The importance of aspect ratio and application to deformation bands. J. Struct. Geol. 2002, 24, 1389-1411. [CrossRef]

62. Schultz, R.A.; Okubo, C.H.; Wilkins, S.J. Displacement-length scaling relations for faults on the terrestrial planets. J. Struct. Geol. 2006, 28, 2182-2193. [CrossRef]

63. Ridley, J. The relations between mean rock stress and fluid flow in the crust: With reference to vein- and lode-style gold deposits. Ore Geol. Rev. 1993, 8, 23-37. [CrossRef]

64. Schultz, R.A.; Soliva, R.; Fossen, H.; Okubo, C.H.; Reeves, D.M. Dependence of displacement-length scaling relations for fractures and deformation bands on the volumetric changes across them. J. Struct. Geol. 2008, 30, 1405-1411. [CrossRef]

65. Weinberg, R.F.; van der Borgh, P. Extension and gold mineralization in the Archean Kalgoorlie Terrane, Yilgarn Craton. Precambrian Res. 2008, 161, 77-88. [CrossRef]

66. Dirks, P.H.G.M.; Charlesworth, E.G.; Munyai, M.R. Cratonic extension and archaean gold mineralisation in the Sheba-Fairview Mine, Barberton Greenstone Belt, South Africa. S. Afr. J. Geol. 2009, 112, 291-316. [CrossRef]

67. Seward, T.M. The hydrothermal geochemistry of gold. In Gold Metallogeny and Exploration; Springer: New York, NY, USA, 1991; pp. 37-62.

68. Seward, T.M. Thio complexes of gold and the transport of gold in hydrothermal ore solutions. Geochimica et Cosmochimica Acta 1973, 37, 379-399. [CrossRef]

69. Kerrich, R.; Goldfarb, R.; Groves, D.; Garwin, S. The geodynamics of world-class gold deposits: Characteristics, space-time distribution, and origins. In Gold in 2000; Society of Economic Geologists, Inc.: Littleton, CO, USA, 2000; Volume 13, pp. 501-551.

70. Campbell McCuaig, T.; Kerrich, R. P-T-t-deformation-fluid characteristics of lode gold deposits: Evidence from alteration systematics. Ore Geol. Rev. 1998, 12, 381-453. [CrossRef]

71. Likhoidov, G.G.; Plyusnina, L.P.; Shcheka, Z.A. The behavior of gold during listvenitization: Experimental and theoretical simulation. Dokl. Earth Sci. 2007, 415, 723-726. [CrossRef]

72. Chamberlain, C.M. Geology and Genesis of the Bulyanhulu Gold Deposit, Sukumaland Greenstone Belt, Tanzania. Unpublished Ph.D. Thesis, Imperial College, London, UK, 2003; p. 410.

73. Chamberlain, C.M.; Tosdal, R.M. U-Pb Geochronology of the Lake Victoria Greenstone Terrane, Tanzania; Anglo-Gold Ashanti internal report; Mineral Deposit Research Unit, The University of British Columbia: Vancouver, BC, Canada, 2007; p. 43.

74. Vos, I.M.A.; Bierlein, F.P.; Standing, J.S.; Davidson, G. The geology and mineralisation at the golden pride gold deposit, Nzega Greenstone Belt, Tanzania. Miner. Depos. 2009, 44, 751. [CrossRef]

75. Angelier, J.; Mechler, P. Sur une méthode graphique de recherche des contraintes principales également utilisable en tectonique et en séismologie: La méthode des dièdres droits. Bulletin de la Société Géologique de France 1977, 7, 1309-1318. [CrossRef]

76. Delvaux, D.; Sperner, B. New aspects of tectonic stress inversion with reference to the tensor programme. Geol. Soc. Lond. Spec. Publ. 2003, 212, 75-100. [CrossRef]

77. Angelier, J. Fault slip analysis and palaeostress reconstruction. In Continental Deformation; Hancock, P.L., Ed.; Pergamon: Oxford, UK, 1994; pp. 101-120.

78. Etchecopar, A.; Vasseur, G.; Daignieres, M. An inverse problem in microtectonics for the determination of stress tensors from fault striation analysis. J. Struct. Geol. 1981, 3, 51-65. [CrossRef]

79. Lisle, R.J. Principal stress orientations from faults: An additional constraint. Ann. Tecton. 1987, 1, 155-158.

80. Allmendinger, R.W. Faultkinwin, Version 1.1: A Program for Analyzing Fault Slip Data for Windows ${ }^{\mathrm{TM}} 2001$. Available online: https:/ / www.scienceopen.com/document?vid=d520a2b8-1b84-41f7-b341-8479edd4eb19 (accessed on 21 April 2018). 
81. Cladouhos, T.T.; Allmendinger, R.W. Finite strain and rotation from fault slip data. J. Struct. Geol. 1993, 15, 771-784. [CrossRef]

82. Molnar, P. Average regional strain due to slip on numerous faults of different orientations. J. Geophys. Res. 1983, 88, 6430-6432. [CrossRef]

83. Twiss, R.J.; Unruh, J.R. Analysis of fault slip inversions: Do they constrain stress or strain rate? J. Geophys. Res. 1998, 101, 8335-8361. [CrossRef]

84. Sperner, B.; Müller, B.; Heidbach, O.; Delvaux, D.; Reinecker, J.; Fuchs, K. Tectonic stress in the Earth's crust: Advances in the world stress map project. Geol. Soc. Lond. Spec. Publ. 2003, 212, 101-116. [CrossRef]

2018 by the authors. Licensee MDPI, Basel, Switzerland. This article is an open access article distributed under the terms and conditions of the Creative Commons Attribution (CC BY) license (http:/ / creativecommons.org/licenses/by/4.0/). 